ESTUDIOS 

REVISTA DE DERECHO UNED, NÚM. 10, 2012

\section{LA PRESUNCIÓN DE PATERNIDAD Y LA DETERMINACIÓN DE LA FILIACIÓN MATRIMONIAL: NOTAS SOBRE LOS ARTÍCULOS 116 Y 117 DEL CÓDIGO CIVIL}

ENCARNACIÓN ABAD ARENAS ${ }^{1}$

Becaria de Investigación del Departamento de Derecho Civil UNED

Resumen: En este artículo abordaremos el análisis de la determinación de la filiación matrimonial, y, en particular, la presunción de paternidad prevista por el Código civil y aplicable a los hijos nacidos después de la celebración del matrimonio y antes de los trescientos días siguientes a su disolución o a la separación legal o de hecho de los cónyuges. En el texto atenderemos al contenido del Código civil de Cataluña, donde su regulación difiere en algunos aspectos respecto de lo preceptuado por el Código civil. Asimismo, estudiaremos la destrucción de la presunción de paternidad, de conformidad a lo previsto por el artículo 117 del Código civil, así como a sus requisitos y excepciones. Por último, planteamos alguno de los supuestos en que puede existir cierta colisión entre los artículos 116 y 117 del Código civil.

Abstract: In this article we will analysis of the marriaged filiation, and the presumption of paternity. When the mother is or has been married, her husband is presumed to be the father of the children born during the coverture. Also, we study the content of the Civil

1 El trabajo se incluye entre los resultados obtenidos en el marco del Programa de promoción de la investigación como Becaria de Investigación del Departamento de Derecho civil de la UNED dirigido por el Catedrático de Derecho Civil Prof. Carlos Lasarte Álvarez, siendo la Directora de dicha Beca la Profesora $\mathrm{M}^{\mathrm{a}}$ Fernanda Moretón Sanz; a ambos les agradezco el apoyo prestado, así como las observaciones que me han sugerido en la revisión de este trabajo. 
Code of Catalonia, where their regulation is diferent of de Civil Code. Also about the destruction of the husband when is presumed to be the father of the child; and, of conformity to that foreseen by the article 117 of the civil Code. Last, we study the articles 116 and 117 of the civil Cod.

Palabras clave: Filiación matrimonial; Presunción de Paternidad

Key Words: Marriaged filiation; adjudication and presumption of Paternity

Sumario: I. Planteamiento preliminar. II. La presunción de paternidad: 1. La naturaleza de la presunción del artículo 116 del Código civil. 2. La doble presunción. 3. Matrimonio celebrado por poderes. 4. Concepción anterior al matrimonio. 5. Hijo de concepción nupcial nacido dentro el periodo de los ciento ochenta días. 6. Presupuestos del artículo 116 del Código civil e inseminación artificial homóloga. II. La determinación de la paternidad: 1. Declaración auténtica. A) Excepciones. B) Capacidad. 2. Disolución y Separación de hecho o de Derecho de los cónyuges: cuestiones sobre el cómputo del plazo. III. Colisión de presunciones. IV. Reflexiones conclusivas. VI. Bibliografía. VII. Índice de resoluciones.

\section{PLANTEAMIENTO PRELIMINAR}

El Código civil, en lo que al objeto de este estudio se refiere, fue reformado por la Ley 11/1981, de 13 de mayo, en materia de filiación, patria potestad y régimen económico del matrimonio. Dentro de las finalidades de esta norma, cabe destacar, entre otras, la de garantizar la igualdad de los hijos ante la Ley con independencia de su filiación $\mathrm{y}$, en particular, solventar las dificultades que planteaba la antigua imposibilidad de impugnar la paternidad del hijo nacido constante matrimonio.

Sabido es que la Constitución española abrogó en sus artículos 14 y 39.2, las diferencias entre los denominados en épocas precedentes, hijos legítimos o ilegítimos, de modo que en justa consecuencia, el Código civil -gracias a la mencionada reforma- solo distingue entre filiación determinada por naturaleza y por adopción y, por lo que se refiere a la primera entre la filiación matrimonial o no matrimonial, teniendo en cuenta que todas surten idénticos efectos.

Por su parte, con la reforma se facilita la investigación de la pa- 
ternidad en los procesos de reclamación frente a los procesos de impugnación. Y, en particular, en los procesos que pretendan la constatación por medio de la acción de reclamación de la verdadera paternidad manifestada por la posesión de estado -matrimonial o no-, el Código civil permite la determinación judicial de la paternidad, con la única excepción de la existencia de otra paternidad legalmente establecida.

Con todo, uno de los mayores problemas que la impugnación de la paternidad de los hijos nacidos durante el matrimonio, se concreta en si los afectados tienen, o no, las mismas oportunidades para investigar la paternidad.

\section{LA PRESUNCIÓN DE PATERNIDAD}

\section{1) La naturaleza de la presunción del artículo 116 del Código Civil}

Dice el artículo 116 del Código civil: «Se presumen hijos del marido los nacidos después de la celebración del matrimonio y antes de los trescientos días siguientes a su disolución o a la separación legal o de hecho de los cónyuges». En este sentido, la paternidad de un hijo nacido constante matrimonio viene determinada por medio de la ‘presunción de paternidad, regulada por el mencionado precepto.

Por tanto, esta presunción determina la paternidad matrimonial de forma extrajudicial, ya que se producirá cuando sean acreditadas en la forma establecida por la Ley ciertas circunstancias en virtud de las cuales se estima probado el supuesto de hecho en que la filiación descansa ${ }^{2}$. La presunción legal surge porque la paternidad ni es fácil de demostrar ${ }^{3}$, ni automática o inequívoca, excepto en casos de inseminación artificial homóloga, donde la presunción legal de paternidad descansa sobre la verdad biológica del esposo ${ }^{4}$.

2 Vid., CÁMARA ÁLVAREZ: «El nuevo derecho de la filiación», en AA. VV., El nuevo Derecho de la familia español, Reus, Madrid, 1982, pág. 43.

3 Así, la vieja STS de 16 de abril de 1969, advertía que: "Como la paternidad es un hecho de difícil prueba, nuestro CC establece una doble presunción; explicita la relaciona con el tiempo de concepción, presumiéndose legítimos los nacidos dentro de cierto plazo e, implícita en orden a la paternidad, presumiéndose que el marido de la madre es el padre de los hijos concebidos durante el matrimonio, presunciones que solo deben regir en los supuestos de convivencia».

${ }^{4}$ En este punto, vid., LEONSEGUI GUILLOT: «Problemas jurídicos planteados por las nuevas técnicas de reproducción asistida, $B F D, 8-9,1995$, págs. 237-264; «La 
De modo que, la deducción legal supone que los hijos de la mujer casada tienen como progenitor a su marido, debido al principio de fidelidad mutua y a la obligación de convivencia que se impone a los esposos, de conformidad con lo previsto por los artículos $68^{5}$ y $69^{6}$ del Código civil ${ }^{7}$.

Por su parte, en lo relativo a la paternidad matrimonial, el Código civil de Cataluña ${ }^{8}$ en su artículo 235-5 establece que: «1. Se tienen por hijos del marido los nacidos después de la celebración del matrimonio y dentro de los trescientos días siguientes a la separación, judicial

maternidad portadora, sustituta, subrogada o de encargo", BFD págs. 1.327-1.354; LÓPEZ PELÁEZ: "Relaciones civiles derivadas de la fecundación post mortem», $B F D, 6,1994$, págs. 19-142; «La filiación de los niños y niñas nacidos en virtud de contratos de gestación por sustitución en el Derecho español», Derecho de la persona: acogimiento y adopción, discapacidad e incapacitación, filiación y reproducción asistida, personas mayores, responsabilidad penal del menor y otras cuestiones referidas a la persona como sujeto del derecho, Isaac RAVETLLAT BALLESTÉ (Coord.), Barcelona, 2011, págs. 89-136; JIMÉNEZ MUÑOZ: La reproducción asistida y su régimen jurídico, Madrid, 2012.

5 Precepto redactado por el apartado uno del artículo primero de la Ley 15/2005, de 8 de julio, por la que se modifican el Código Civil y la Ley de Enjuiciamiento Civil en materia de separación y divorcio; vid., sobre esta reforma MORETÓN SANZ, «El nuevo sistema de protección de la persona con autonomía limitada: de la incapacitación judicial a la discapacidad y dependencia», La protección de las personas mayores, Carlos LASARTE ÁLVAREZ (Dir.), y M. ${ }^{a}$ Fernanda MORETÓN SANZ (Coord.),Madrid, 2007, pág.33 nt. 6 y la bibliografía allí citada.

6 Precepto redactado por Ley 30/1981, de 7 julio, por la que se modifica la regulación del matrimonio en el Código Civil y se determina el procedimiento a seguir en las causas de nulidad, separación y divorcio.

7 En este sentido, RIVERO HERNÁNDEZ sostiene que «la presunción de paternidad se justifica sobre dos puntos: a) la presunción de convivencia de los cónyuges [art. 69 CC] y la cohabitación o relación sexual de los mismos, que es a la vez derecho y deber de matrimonio [art. $68 \mathrm{CC}$ ] y, b) la llamada presunción de concepción, que permite suponer que la concepción del hijo ha ocurrido en un determinado plazo -el llamado periodo legal de concepción-, dentro de los ciento veinte primeros días de los trescientos que preceden al nacimiento, plazo que es precisamente la diferencia entre los plazos de trescientos días y ciento ochenta días que el legislador considera como máximo y mínimo de gestación respectivamente» (Elementos del Derecho Civil. IV. Derecho de familia, Vol. II, Bosch, Barcelona, 1989, 3. ${ }^{\text {a }}$ ed., pág. 71). También, ROYO MARTÍNEZ dice que «la paternidad supone un acto de credibilidad en la fidelidad de la mujer» (Derecho de familia, Imprenta Suarez, Sevilla, 1949, 1. a ed., pág. 238) y, vid., FÉREZ FERNÁNDEZ y GARRIGA GORINA: «La presunción de paternidad matrimonial del artículo 116 en el caso de separación de hecho. Comentario a la RDGRN de 22 de mayo de 1991», en RJCat, Vol. 91, n. 4, 1992, pág. 1066.

8 Por Ley 25/2010, de 29 de julio, ha sido aprobado el libro segundo del Código civil de Cataluña, relativo a la persona y la familia, que entró en vigor el 1 de enero de 2011, y que deroga la Ley 9/1998, de 15 julio, del Código de familia, la Ley 10/1998, de 15 de julio, de uniones estables de pareja y la Ley 19/1998, de 28 de diciembre, sobre situaciones convivenciales de ayuda mutua. 
o de hecho, de los cónyuges o a la declaración de nulidad o a la disolución del matrimonio».

En particular, conviene precisar que aunque el artículo 116 del Código civil establece que nos encontramos ante una presunción única, lo cierto es que ésta contiene algunas matizaciones. Así, RIVERO HERNÁNDEZ ${ }^{9}$ sostiene que «el artículo 116 del Código civil es una presunción relativa, ya que admite prueba en contrario por la vía de las acciones de impugnación [arts. 136 y 137 CC]», si bien aclara que «no puede hablarse de una doble presunción de paternidad, sino que la presunción de paternidad es única, siendo menos enérgica la del artículo 117». Por su parte, DÍEZ-PICAZO y GULLÓN BALLESTEROS $^{10}$, entienden que la presunción del artículo 117 del Código civil «no es que deje de ser operante, sino que faculta al marido para destruirla, mediante declaración auténtica en contrario formalizada dentro de plazo».

De lo anterior, cabe afirmar que todos los hijos nacidos después del matrimonio de sus padres, son presuntamente del marido, aunque hayan sido concebidos antes de la celebración del matrimonio ${ }^{11}$. Sin embargo, algunos autores ${ }^{12}$ sostienen la existencia de una doble

${ }^{9}$ La presunción de paternidad legítima, Estudio de Derecho Comparado y Derecho Español, Tecnos, Madrid, 1971, págs. 295-297.

10 Instituciones de Derecho civil, Derechos Reales, Derecho de Familia, Derecho de Sucesiones, Vol. II, Tecnos, Madrid, 1995, pág. 562. Para VERDERA SERVER no hay ninguna distinción, sino que la presunción es siempre la misma, la del artículo 116 del Código civil, al contemplar dentro de su ámbito a los nacidos dentro de los 180 días (vid., Determinación y acreditación de la filiación, Ed. Boch, Barcelona, 1993, págs. 161-162). Según GARCÍA CANTERO, el artículo 117 constituye una aplicación o desarrollo del artículo 116 (vid., "La filiación», en Derecho Civil español, Común y Foral. IV. Derecho de Familia, Relaciones paternofiliales y tutelares, Vol. II, de José CASTÁN TOBEÑAS, Reus, Madrid, 1985, 9. ${ }^{\text {a }}$ edición revisada y puesta al día, pág. 102 y, vid., las aportaciones de DÍEZ DEL CORRAL RIVAS: «La inscripción de la filiación en el Registro civil», $R D N$, n. 123, enero-marzo, 1-1984, pág. 23.

11 Vid., CORDERO CUTILLAS: La impugnación de la paternidad matrimonial, Colección de Estudios Jurídicos, n. 6, Publicación de la Universidad Jaime Primero, Castellón, 2001, pág. 23.

12 En este sentido, entre otros, LLEDO YAGÜE habla de una presunción absoluta [art. 116 CC] y de otra relativa [art. 117 CC] (Acciones de Filiación, Ed., La Ley, Madrid, 1987, 2. ${ }^{\text {e }}$ ed., pág. 151). Por su parte, MARTÍN-GRANIZO FERNÁNDEZ distingue entre presunción legal ordinaria [art. $116 \mathrm{CC}$ ] y extraordinaria [art. $117 \mathrm{CC}$ ] (Código civil. Doctrina y Jurisprudencia, T. I, José Luis ALBACAR LÓPEZ (Dir.), Trivium, Madrid, 1991, págs. 815-816). Para PEÑA BERNALDO DE QUIRÓS se trata de una presunción provisional [art. $117 \mathrm{CC}$ ] y otra definitiva [art. $116 \mathrm{CC}$ ] («Comentario a los artículos 108 a 141 del Código civil (De la paternidad y filiación)», en Comentarios a las Reformas del Derecho de Familia, Vol. I, Tecnos, Madrid, 1984, pág. 870) y, CÁMARA ÁLVAREZ diferencia entre una presunción de primer grado o más fuerte y otra 
presunción a efectos de la declaración de desconocimiento contemplada por el artículo 117 del Código civil.

\section{2) La doble presunción}

Dice el artículo 117 del Código civil, que: «Nacido el hijo dentro de los ciento ochenta días siguientes a la celebración del matrimonio, podrá el marido destruir la presunción mediante declaración auténtica en contrario [...]». Y, por su parte, el Código civil de Cataluña en su artículo 235-6 prevé que: «1. Si el hijo nace dentro de los ciento ochenta días siguientes a la celebración del matrimonio, el marido puede dejar sin efecto la determinación de la filiación que resulta del artículo 235-5 declarando que desconoce su paternidad [...]».

En este sentido y como aprecia CORDERO CUTILLAS ${ }^{13}$, se puede entender que la presunción prevista por este precepto es más débil que la establecida por el artículo 116, debido a que si el hijo ha nacido después de la celebración del matrimonio, pero es de concepción anterior, cabe suponer que el deber de fidelidad mutua y de convivencia [arts. 68 y $69 \mathrm{CC}$ ], en principio, no existirá, ya que se encuentra en la fase anterior al enlace. Por ello, el legislador permite la posibilidad de negar la paternidad, sin necesidad de acudir a la vía judicial, puesto que en este caso es posible que el hijo no sea suyo.

Por otra parte, la finalidad de este precepto, indudablemente, se encuentra en las consecuencias planteadas por la legislación anterior $^{14}$, donde la presunción de paternidad estaba condicionada a que existiese un comportamiento activo del padre y, exclusivamente, en estas circunstancias se presumía su paternidad legítima ${ }^{15}$. Mientras que en la actualidad se ha producido un notable cambio, debido a

de segundo grado o más débil (Comentarios al Código Civil y Compilaciones Forales, T. III, Vol. I, Manuel ALBALADEJO GARCÍA (Dir.), Edersa, Madrid, 1984, pág. 217).

${ }^{13}$ La impugnación de la paternidad..., op. cit., pág. 24.

14 Literalmente era: Libro Primero De las personas, Título V De la paternidad y filiación, Capítulo Primero De los hijos legítimos: Artículo 108: «Se presumirán hijos legítimos los nacidos después de los ciento ochenta días siguientes al de la celebración del matrimonio y antes de los trescientos días siguientes a su disolución o a la separación de los cónyuges». Artículo 110: «Se presumirá legítimo el hijo nacido dentro de los ciento ochenta días siguientes a la celebración del matrimonio, si concurriere alguna de estas circunstancias: $1 .^{\mathrm{a}}$ Haber sabido el marido, antes de casarse, el embarazo de su mujer. $2{ }^{\mathrm{a}}{ }^{\mathrm{H}}$ Haber consentido, estando presente, que se pusiera su apellido en la partida de nacimiento del hijo que su mujer hubiese dado a luz. 3. ${ }^{a}$ Haberlo reconocido como suyo expresa o tácitamente».

15 Vid., CÁMARA ÁLVAREZ, Comentarios al Código Civil..., op. cit., pág. 211. 
que con la modificación practicada por Ley 11/1981, de 13 de mayo, los hijos nacidos dentro del periodo establecido por el artículo 117 del Código civil ‘en principio〉 son hijos matrimoniales, salvo que conste y se pueda realizar la correspondiente declaración. Con ello el legislador evita que la madre o el hijo tengan que acudir a una acción de reclamación de paternidad cuando el hijo hubiese nacido dentro del periodo de los ciento ochenta días. Presunción que, indudablemente, se mantendrá mientras que el esposo no formule la declaración auténtica en contrario ${ }^{16}$.

Asimismo, el motivo que permite al esposo desconocer la paternidad del menor que nace dentro del periodo previsto por el precepto, sin necesidad de acudir a la vía judicial, se justifica en que la concepción, indudablemente, se ha producido con anterioridad a la celebración de las nupcias, no exigiéndose a las partes la obligación de convivencia, por lo que la presunción iuris prevista por el artículo $69^{17}$ del Código civil, resulta inoperante.

RIVERO HERNÁNDEZ ${ }^{18}$ establece que «[...] la presunción no puede tener la misma fuerza cuando la cohabitación presunta entre cónyuges cae en una época matrimonial en que hay derecho y obligación que cuando corresponde con época anterior; así, cuando por haber nacido el hijo dentro de los primeros ciento ochenta días del matrimonio y ser de forzosa concepción antenupcial, no cabe hablar de una presunción de cohabitación entre los presuntos progenitores, aunque ella sea verosímil» $\mathrm{y}$, añade que "como el derecho no puede ignorar la diferencia real y vivencial que hay entre esas dos situaciones, hace menos enérgica la presunción en el segundo caso, que tiene tratamiento separado en el artículo 117 del Código civil [...]».

Sin embargo, dos son las causas que podrían originar que el esposo no formulase la correspondiente declaración auténtica en el plazo previsto. Son, de una parte, la convicción de que el menor lo concibió él -es decir, que conocía el embarazo de su mujer y, por tanto, supone un reconocimiento tácito de su paternidad ${ }^{19}-\mathrm{y}$, de otra, el desconocimiento del estado de gestación de su esposa ${ }^{20}$.

16 Vid., CORDERO CUTILLAS, La impugnación de la paternidad..., op. cit., pág. 24.

17 «Se presume, salvo prueba en contrario, que los cónyuges viven juntos».

18 Elementos del Derecho Civil..., op. cit., págs. 71-72.

19 Vid., CORDERO CUTILLAS, La impugnación de la paternidad..., op. cit., pág. 24.

20 En este sentido, SANCHO REBULLIDA, entiende que "con la facultad concedida por el artículo 117 del Código civil, hay un componente negocial junto al legal en la determinación de la patrimonialidad del hijo que nace bajo esas circunstancias» y, por tanto, afirma que «el no desconocimiento se valora como reconocimiento tácito de autoría» («La filiación en la Ley Foral de 1 de abril de 1987», en $R J N a, 1990$, págs. 38-39). 
En virtud de lo anterior, la excepción establecida por el artículo 117 del Código civil apunta a que la Ley lo que presume es que el marido desconoce el estado de su mujer, debido a que en caso contrario no tendría sentido la posibilidad que se le confiere para enervar la presunción prevista por el artículo 116, ya que si el esposo es sabedor del estado de gestación de ésta no podrá destruir la presunción sin que medie el consentimiento de la madre ${ }^{21}$.

A este respecto, GETE ALONSO ${ }^{22}$ sostiene que «en caso de violación, aunque haya una manifestación expresa a no admitir como suyo al hijo o sea notorio que no fue concebido por él, tendrá que acudirse a las acciones de impugnación judicial, por estar vedada la acción de desconocimiento»; la autora parte de que «quien se casa conociendo el embarazo de la madre, o es el padre o aunque sepa que no es el padre o lo niegue, está dispuesto a actuar como tal, quedándole en todo caso abierta la vía de la impugnación».

Sin embargo, OCAÑA RODRÍGUEZ ${ }^{23}$ dice que «si la víctima del delito a cargo de un tercero, víctima sobre todo de violación vaginal, fue una mujer casada, el Tribunal penal puede descartar la presunción de paternidad del marido, -a tenor de las peticiones de las partes- sin necesidad, por tanto, de verdadera impugnación».

A este respecto, el Código civil de Cataluña ${ }^{24}$, permite el desconocimiento de la paternidad en esta situación, si la declaración del marido concurre con el consentimiento de su esposa.

En suma, la inoperancia de la declaración del esposo en tiempo hábil ${ }^{25}$, origina que si el hijo hubiese nacido dentro de los ciento ochenta días siguientes a la celebración del matrimonio, no se le

21 En este sentido, DÍEZ-PICAZO y GULLÓN BALLESTEROS, sostienen que «parece lógico pensar que si el padre contrae matrimonio con la madre conociendo el embarazo, asume la paternidad como si se tratara de un reconocimiento tácito que impide la declaración individual del marido» (Sistema de Derecho civil. IV. Derecho de Familia. Derecho de Sucesiones, Vol. IV, Luis DÍEZ-PICAZO y Antonio GULLÓN BALLESTEROS (coord.), Tecnos, Madrid, 2002, 6. ${ }^{\text {a }}$ ed., pág. 255) y, vid., PEÑA BERNALDO DE QUIRÓS, «Comentario a los artículos... op. cit., pág. 853.

${ }^{22}$ La nueva regulación de la filiación en el derecho catalán, Tirant lo Blanch, Valencia, 1992, págs. 853 y ss.

${ }^{23}$ La filiación en España, Comares, Granada, 1993, pág. 47.

${ }^{24}$ Dice el «artículo 235-6. 2. a) Si el marido ha conocido el embarazo antes de contraer matrimonio, salvo que la declaración a que se refiere el apartado 1 se haya hecho con el consentimiento de la mujer».

25 En este sentido, vid., CORDERO CUTILLAS, La impugnación de la paternidad..., op. cit., pág. 25. Por el contrario para CÁMARA ÁLVAREZ, el fundamento del artículo 117 del Código civil se encuentra en el conocimiento del marido del embarazo de su esposa (Comentarios al Código Civil..., op. cit., págs. 216-217). 
atribuya la paternidad únicamente por la presunción del artículo 116 del Código civil -única presunción existente-, sino también por la confluencia del reconocimiento tácito efectuado por él, salvo que efectué la declaración auténtica en contrario. Con ello se evita -a diferencia de la legislación anterior- que la madre tenga que acudir a una acción de reclamación de paternidad matrimonial, puesto que si no efectúa la declaración auténtica en contrario, se sobreentiende que el silencio del esposo supone el reconocimiento de la paternidad.

En definitiva, si el esposo reconoce como suyo el fruto acaecido de esa relación prenupcial, únicamente podrá destruir la presunción de paternidad por medio de las acciones de impugnación, debiendo demostrar de forma cierta, que el menor no es suyo. De ello, se deduce que la filiación le es atribuida, más que por la presunción, por el consentimiento ${ }^{26}$.

\section{3) Matrimonio celebrado por poderes}

En este supuesto, DÍEZ DEL CORRAL RIVAS ${ }^{27}$ establece el ejemplo siguiente: «ante un matrimonio celebrado por poderes en el que nunca hayan cohabitado los cónyuges, si la mujer da a luz dentro de los ciento ochenta días siguientes a la boda, no parece razonable entender que entre en juego, la presunción de paternidad de esposo. El juego conjunto de los artículos 116, 117 y 69 parece abonar esta conclusión y la misma significa que el esposo ante un caso como el explicado, no ha de verse obligado a destruir una presunción que no existe. No habrá pues aquí título de atribución de la filiación matrimonial y, si la misma ha sido inscrita indebidamente en el Registro, el marido no tendrá realmente que ejercitar una acción de impugnación de la paternidad por la vía del artículo 136 del Código civil, sino que deberá solicitar la rectificación del asiento inexacto por el camino del juicio declarativo del artículo 92 de la Ley del Registro Ci$\operatorname{vil}^{28}[\ldots] »$.

Por su parte, CORDERO CUTILLAS ${ }^{29}$, entiende que este supuesto de hecho viene explicitado en el artículo 117 del Código civil, al pre-

26 Vid., BLASCO GASCÓ: «La filiación», en AA. VV., Derecho de familia, Vicente Luis MONTÉS PENADÉS (Coord.), Tirant lo Blanch, Valencia, 1991, pág. 383; CORDERO CUTILLAS, La impugnación de la paternidad..., op. cit., pág. 25.

27 «La inscripción de la filiación en el Registro civil», $R D N$, n. 123, enero-marzo, 11984, pág. 23.

${ }^{28}$ Ley de 8 de junio de 1957, reguladora del Registro Civil.

${ }^{29}$ La impugnación de la paternidad..., op. cit., pág. 52. 
ver que aunque la presunción del artículo 116 rige en este caso, esta presunción puede quedar inoperante mediante un comportamiento activo del padre. Mientras que DÍEZ DEL CORRAL da por supuesto que no la ha ejercitado y, en consecuencia, si el esposo no realiza el correspondiente medio extrajudicial para rebatir la presunción establecida por virtud del artículo 116 del Código civil ésta se mantendrá y, por tanto, tendrá que ser destruida por la vía judicial, de conformidad con lo previsto por el artículo $92^{30}$ de la Ley del Registro Civil, debiéndose acudir a un juicio declarativo de rectificación del Registro en el que no será posible la rectificación del Registro conforme al expediente gubernativo, pero sí la rectificación del asiento, de acuerdo con la legislación del Registro Civil [art. 97.1 ${ }^{31}$ LRC y párrafo primero del art. $\left.114^{32} \mathrm{CC}\right]$.

En síntesis, en este caso, el artículo 97.1 de la Ley del Registro Civil, no será de aplicación, puesto que se refiere a los expedientes gubernativos para rectificar las inscripciones del Registro, y tanto el párrafo segundo del artículo 114 del Código civil, como el párrafo primero del artículo 92 de la Ley del Registro Civil remiten a la vía judicial por medio de la aplicación del articulado del Código civil. Preceptos dedicados a la impugnación de la paternidad matrimonial.

Por cuanto atañe a los medios de prueba que se pudieran alegar a su favor, será suficiente con manifestar la lejanía física. Lejanía que será fácilmente demostrable, debido a que contrajo matrimonio por poderes, por lo que no será necesario solicitar la realización de pruebas biológicas.

Por lo que a los plazos se refiere, conviene precisar que aunque el plazo es breve éste no comenzará a correr mientras el padre ignore el nacimiento del hijo, por lo que será necesario que acuda a la vía judicial [arts. 136 y ss. CC]. Sin embargo, si el esposo reconoce como suyo el fruto de esa relación prenupcial, únicamente podrá negar la paternidad por vía de las acciones de impugnación, debiendo de-

30 «Las inscripciones sólo pueden rectificarse por sentencia firme en juicio ordinario. La demanda se dirigirá contra el Ministerio Fiscal y aquellos a quienes se refiere el asiento que no fueren demandantes. En este juicio no tiene lugar la restricción de pruebas que establece el artículo $2 »$.

31 «1. Los expedientes gubernativos a que se refiere esta Ley se sujetarán a las reglas siguientes: 1. Puede promoverlos o constituirse en parte cualquier persona que tenga interés legítimo en los mismos. Están obligados a ello los que, en su caso, deben promover la inscripción».

32 «Los asientos de filiación podrán ser rectificados conforme a la Ley de Registro Civil, sin perjuicio de lo especialmente dispuesto en el presente título sobre acciones de impugnación». 
mostrar que el niño no es suyo y, atribuyéndosele en este supuesto la filiación por consentimiento.

\section{4) Concepción anterior al matrimonio}

En caso de que la concepción haya sido anterior al matrimonio, conviene precisar que si al esposo se le ha hecho creer que el hijo ha sido fruto de una gestación normal, cuyo nacimiento se ha producido de forma prematura -por ejemplo, a los ciento ochenta y cinco días posteriores al matrimonio de los padres-, aunque lógico es que éste tenga que acudir a la vía judicial, para poder rebatir su título de determinación legal ${ }^{33}$-es decir, mediante las acciones de impugnación de la paternidad matrimonial [arts. 136 y 137 CC]-, quizás sería más correcto, por analogía, acudir al artículo $138^{34}$ del Código civil. En el fondo lo que subsiste es un vicio del consentimiento, fundado en la creencia por éste de que el hijo fue concebido constante matrimonio, cuando en realidad se concibió con anterioridad ${ }^{35}$.

Por su parte, CÁMARA ÁLVAREZ ${ }^{36}$ considera que cuando es de aplicación el artículo 138 por ser un supuesto contemplado en el artículo 117 del Código civil, si no concurre vicio de consentimiento, se podrá reconducir la impugnación de la filiación conforme a los artículos 136 y $137^{37}$ del Código civil.

${ }^{33}$ Respecto del debate sobre título de legitimación, atribución o determinación, vid., entre otros, CÁMARA ÁLVAREZ, Comentarios al Código Civil..., op. cit., págs. 119 y 145146; PEÑA BERNALDO DE QUIRÓS, «Comentario a los artículos..., op. cit., págs. 833845; LLEDO YAGÜE, op. cit., pág. 163; RIVERO HERNÁNDEZ, Elementos del Derecho Civil..., op. cit., pág. 73; OCAÑA RODRÍGUEZ, op. cit., págs. 66-72; VERDERA SERVER, op. cit., págs. 71-72; QUESADA GONZÁLEZ: Promiscuidad sexual y determinación jurídica de la paternidad, Tecnos, Madrid, 1993, págs. 191-192; CASTRO Y BRAVO: Derecho Civil de España, Ed. Civitas, Madrid, 1984, págs. 79-80; GARRIDO MELERO: «Reflexiones sobre el Derecho de filiación en Cataluña y sus relaciones con el Código Civil», Revista Jurídica del Notariado, n. 7, Julio-Septiembre 1993, págs. 202-204; DÍEZ DEL CORRAL RIVAS, op. cit., págs. 21-24; PUIG BRUTAU: Fundamentos de Derecho Civil. IV. Familia, matrimonio, filiación, ed. Bosch, Barcelona, 1985, 2. a ed., p. 193.

34 «Los reconocimientos que determinen conforme a la Ley una filiación matrimonial podrán ser impugnados por vicio de consentimiento conforme a lo dispuesto en el artículo 141. La impugnación de la paternidad por otras causas se atendrá a las normas contenidas en esta sección».

${ }_{35} \mathrm{Vid}$., en este sentido, las aportaciones de CORDERO CUTILLAS, La impugnación de la paternidad..., op. cit., pág. 25.

36 «El nuevo derecho..., op. cit., pág. 50.

37 Dicen los mencionados preceptos: «Artículo 136. -El marido podrá ejercitar la acción de impugnación de la paternidad en el plazo de un año contado desde la inscripción de la filiación en el Registro Civil. Sin embargo, el plazo no correrá mientras 
En este sentido, CORDERO CUTILLAS -con acierto- sostiene que en función de la aplicación de uno u otro precepto las consecuencias serán distintas. Así, si se aplica el artículo 136 del Código civil, el esposo dispondrá del plazo de un año, que comenzará desde la inscripción de la filiación en el Registro civil, con la única excepción del desconocimiento del nacimiento, en cuyo caso, dicho plazo se iniciará desde el momento en que lo conozca, mientras que si se aplica lo previsto por el artículo 138, este plazo -de un año- empezará desde que salga de su error.

Asimismo, conviene puntualizar que resulta indiferente el hecho de que el esposo haya estado o no ausente durante el nacimiento del menor, puesto que en caso de no estar presente, lo normal es que desconozca el estado de madurez del recién nacido y, en consecuencia, si su esposa le comunica el nacimiento de aquél, lógico es que piense que se trata de una gestación normal, aunque prematura. Mientras que si hubiera estado presente y se hubiera dado cuenta de que el hijo no nació prematuramente, debido a que su nacimiento tuvo lugar a los ciento ochenta y cinco días siguientes a la celebración del matrimonio, se le soslaya la posibilidad prevista por el artículo 117 del Código civil -para aquellos hijos que nazcan dentro los ciento ochenta días que indica dicho precepto-, con la finalidad de que formule la correspondiente acción de desconocimiento ${ }^{38}$.

el marido ignore el nacimiento. -Si el marido falleciere antes de transcurrir el plazo señalado en el párrafo anterior, la acción corresponde a cada heredero por el tiempo que faltare para completar dicho plazo. -Fallecido el marido sin conocer el nacimiento, el año se contará desde que lo conozca el heredero». "Artículo 137. -La paternidad podrá ser impugnada por el hijo durante el año siguiente a la inscripción de la filiación. Si fuere menor o incapaz, el plazo contará desde que alcance la mayoría de edad o la plena capacidad legal. -El ejercicio de la acción, en interés del hijo que sea menor o incapacitado, corresponde, asimismo, durante el año siguiente a la inscripción de la filiación, a la madre que ostente la patria potestad o al Ministerio Fiscal. -Si falta en las relaciones familiares la posesión de estado de filiación matrimonial, la demanda podrá ser interpuesta en cualquier tiempo por el hijo o sus herederos».

38 Vid., en este sentido, las Resoluciones de la DGRN, de 10 de febrero de 1996 (RJ 1996, 3409) y 1 de febrero de 1993 (RJ 1993, 1312). En ambas, el hijo de concepción antenupcial había nacido transcurridos los ciento ochenta días de la celebración del matrimonio, en concreto a los ciento noventa y seis días. Como el nacimiento ocurrió exactamente a los ciento noventa y seis días desde el matrimonio de la madre, es obvio que no entran en juego las previsiones del artículo 117 del Código civil y, por tanto, la declaración auténtica del marido, con consentimiento de la mujer, de que conocía el embarazo antes del matrimonio carece de eficacia y no basta según la letra del artículo, para destruir la presunción legal de la paternidad del marido. Es, pues, de plena aplicación el artículo 116 del Código civil corroborado, puesto que marido y mujer han afirmado que la separación de hecho se produjo, a los ocho días en el primer caso y a los veintidós días en el segundo, después de la celebración del matrimonio. 
Sin embargo, lo anterior no tendrá lugar si el hijo nace a los ciento sesenta días siguientes a la celebración del matrimonio -es decir, dentro del periodo marcado por el artículo 117 del Código civil- y el marido piensa que ha sido fruto de una gestación normal de nacimiento prematuro, puesto que si éste sale de su error en ese momento podrá formular la declaración de desconocimiento -solo o con la declaración de su mujer-. Supuesto este último en el que, necesariamente, deberá ser sabedor de que el embarazo se concibió con anterioridad al matrimonio. Por tanto, la declaración podrá ser realizada únicamente por él, con la excepción de que la esposa pueda demostrar que éste conocía su estado de gestación con anterioridad a la celebración del matrimonio ${ }^{39}$.

La doctrina, en este punto, está dividida. En particular, algunos autores $^{40}$, sostienen que el marido sólo tendrá que probar que el niño ha nacido dentro de los ciento ochenta días siguientes al matrimonio, por tanto, si el niño nace dentro dicho plazo se presume que el padre desconoce el embarazo, salvo prueba en contrario. Por el contrario, otro sector doctrinal, entiende que «sería excesivo a todas luces que el marido pudiese destruir la presunción sin más que formular una declaración pura y simple de desconocimiento. Lo razonable es exigir que, al inscribir esa declaración, se justifique de algún modo que el marido desconocía al casarse el embarazo de su mujer y no reconoció expresamente al hijo o realizó algún acto que pueda calificarse de reconocimiento tácito» ${ }^{41}$.

\section{5) Hijo de concepción nupcial nacido dentro del periodo de los ciento ochenta días}

En este caso el esposo, en principio, podrá destruir la presunción de paternidad, debido a que se cumple lo establecido por la Ley, cuando no operen las excepciones que le vetan. Sin embargo, en el Código civil de Cataluña la acción de desconocimiento deviene ineficaz, debido a que en su artículo 235-6 se prevé que: «2. c) Si la madre demuestra la existencia de relaciones sexuales con el marido durante el período legal de la concepción».

En suma, este supuesto contemplado por el artículo 117 del Código civil sigue siendo una presunción, puesto que la Ley lo que pre-

\footnotetext{
39 Vid., CORDERO CUTILLAS, La impugnación de la paternidad..., op. cit., pág. 26.

40 Vid., IBÍDEM.

${ }^{41}$ CÁMARA ÁlVAREZ, Comentarios al Código Civil..., op. cit., págs. 117-118 y 216.
} 
tende es dar a ese hijo la condición de matrimonial una vez reconocido -expresa o tácitamente- o no habiéndose formulado la acción de desconocimiento por el padre, conocido el embarazo de su esposa ${ }^{42}$. Presunción fundada en la cohabitación anterior al matrimonio de los $\operatorname{esposos}^{43}$ y no en el matrimonio en si $^{44}$.

\section{6) Presupuestos del artículo 116 del Código civil e inseminación artificial homóloga}

Dos son los presupuestos necesarios para que concurra la presunción de paternidad contenida en el artículo 116 del Código civil, de una parte, el matrimonio de los padres y más concretamente la convivencia matrimonial ${ }^{45} \mathrm{y}$, de otra, el nacimiento del hijo de mujer casada.

Esta presunción actúa como un medio indirecto y legal de determinación extrajudicial de la paternidad, ante la dificultad de su prueba directa, salvo en los casos de inseminación artificial con material propio del marido ${ }^{46}$.

En caso de la paternidad provocada por medios artificiales, es decir, inseminación artificial homóloga, la presunción legal de paternidad opera de forma inequívoca, debido a que el hijo procede biológicamente del esposo.

Por su parte, la Ley 14/2006, de 26 de mayo, sobre Técnicas de Reproducción Humana Asistida ${ }^{47}$, en su artículo 7.1 establece que: «La filiación de los nacidos con las técnicas de reproducción asistida se regulará por las Leyes civiles, a salvo de las especialidades establecidas en los tres siguientes artículos» ${ }^{48}$. Por tanto, serán de aplicación las

42 Vid., CORDERO CUTILLAS, «Presunción de Paternidad..., op. cit., pág. 204.

$43 \mathrm{Vid}$., PEÑA BERNALDO DE QUIRÓS, "Comentario a los artículos..., op. cit., pág. 870 .

${ }^{44}$ Vid., BLASCO GASCÓ: Derecho de familia, Tirant Lo Blanch, Valencia, 1997, 3. ${ }^{a}$ ed., pág. 380 .

${ }^{45}$ En este sentido, vid., las aportaciones de PEÑA BERNALDO DE QUIRÓS, «Comentario a los artículos..., op. cit., pág. 867; RIVERO HERNÁNDEZ, Elementos del Derecho Civil..., op. cit., pág. 73; CÁMARA ÁLVAREZ, Comentarios al Código Civil..., op. cit., pág. 217; ALBALADEJO GARCÍA: Curso de Derecho Civil. IV. Derecho de

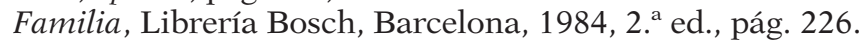

${ }^{46}$ Vid., CORDERO CUTILLAS, La impugnación de la paternidad..., op. cit., pág. 22.

47 Esta Ley deroga la Ley 35/1988, de 22 de noviembre, sobre Técnicas de Reproducción Asistida (BOE de 24 de noviembre. Corrección de errores BOE de 26 de noviembre) y la Ley 45/2003, de 21 de noviembre, por la que se modifica la Ley 35/1988, de 22 de noviembre, sobre Técnicas de Reproducción Asistida (BOE de 22-11-2003).

48 Artículo redactado por Ley 3/2007, de 15 de marzo, reguladora de la rectificación registral de la mención relativa al sexo de las personas. 
normas previstas por los artículos 116 y 117 del Código civil, pero para la paternidad, al haber intervenido medios artificiales -aunque ésta queda determinada conforme a los preceptos del Código civil- influirá en su determinación el consentimiento a dichas técnicas.

Asimismo, el consentimiento prestado para su realización -respecto a la inseminación artificial-, podrá ser considerado, como un reconocimiento tácito de paternidad, con la finalidad de evitar que el esposo ejercite la acción de desconocimiento.

Por su parte, el Código civil en su artículo 108 establece que: «La filiación puede tener lugar por naturaleza y por adopción. La filiación por naturaleza puede ser matrimonial y no matrimonial. Es matrimonial cuando el padre y la madre están casados entre sí» ${ }^{49}$. De modo que la exigencia de tal consentimiento se justifica en que su ausencia podría ser una grave deslealtad tanto moral, como jurídica, constituyéndose como una infracción grave de los derechos conyugales y, pudiendo dar lugar a una separación matrimonial y a un posterior divorcio, sin perjuicio, de otras consecuencias como sería el caso de la determinación de la filiación resultante ${ }^{50}$.

Conviene matizar que, con la mencionada apreciación, se produce un desdoblamiento en los conceptos de paternidad. De una parte, la paternidad biológica, es decir, aquella en la que el material genético procede del marido, su consentimiento implica la convivencia matrimonial y el hijo será inscrito como matrimonial. Como resulta evidente, en principio, la determinación de esta paternidad no origina ningún tipo de problema, puesto que ambas filiaciones -jurídica y biológica- son coincidentes. Por otra parte, siguiendo con el desdoblamiento mencionado, concurre la paternidad jurídica, en la que el material genético procede de un donante, lo que origina una imposibilidad de impugnación, cuando la inseminación se haya verificado con el consentimiento del esposo [art. 8.1 ${ }^{51}$ LTRHA].

En lo relativo a la fecundación asistida de la mujer, el Código civil Catalán ${ }^{52}$ no hace referencia a la presunción, sino a la consideración

49 Artículo redactado por la Ley 11/1981, del 13 de mayo, de modificación del Código Civil en materia de filiación, patria potestad y régimen económico del matrimonio.

50 Vid., RIVERO HERNÁNDEZ, Elementos del Derecho Civil..., op. cit., pág. 152.

51 «1. Ni la mujer progenitora ni el marido, cuando hayan prestado su consentimiento formal, previo y expreso, a determinada fecundación con contribución de donante o donantes, podrán impugnar la filiación matrimonial del hijo nacido por consecuencia de tal fecundación».

52 Dice el «artículo 235-8: 1. Los hijos nacidos a consecuencia de la fecundación 
de hijos matrimoniales. De modo que estos hijos disfrutarán del estatus de hijo matrimonial, por remisión de la Ley a lo establecido en los artículos 116 y 117 del Código civil.

\section{LA DETERMINACIÓN DE PATERNIDAD}

\section{1) Declaración auténtica}

El artículo $117^{53}$ del Código civil permite destruir la presunción de paternidad de los hijos nacidos dentro de los ciento ochenta días siguientes a la declaración del matrimonio mediante una declaración auténtica.

En este punto, la doctrina no es unánime sobre el sentido que ha de darse a la declaración auténtica: autores como RIVERO HERNÁNDEZ $^{54}$ afirman que se ha de formalizar ante el encargado del Registro civil, si bien la doctrina sentada por ALBALADEJO GARCÍA ${ }^{55}$ sostiene que «la autenticidad ha de ser tal que su eficacia dimane de sí misma sin acudir a ningún otro medio de prueba, de forma evidente e inequívoca». Por su parte, PEÑA BERNALDO DE QUIRÓS ${ }^{56}$ aprecia que la declaración auténtica se debe hacer en documento público. Para RODRÍGUEZ ADRADOS ${ }^{57}$, la declaración auténtica «puede ha-

asistida de la mujer, practicada con el consentimiento expreso del cónyuge formalizado en un documento extendido ante un centro autorizado o en un documento público, son hijos matrimoniales del cónyuge que ha dado el consentimiento»

53 «Nacido el hijo dentro de los ciento ochenta días siguientes a la celebración del matrimonio, podrá el marido destruir la presunción mediante declaración auténtica en contrario formalizada dentro de los seis meses siguientes al conocimiento del parto. Se exceptúan los casos en que hubiere reconocido la paternidad expresa o tácitamente o hubiese conocido el embarazo de la mujer con anterioridad a la celebración del matrimonio, salvo que, en este último supuesto, la declaración auténtica se hubiera formalizado, con el consentimiento de ambos, antes del matrimonio o después del mismo, dentro de los seis meses siguientes al nacimiento del hijo».

${ }^{54}$ Elementos del Derecho Civil..., op. cit., pág. 76. También GARCÍA ZARANDIETA, entiende que «debe normalmente ser formalizada ante el encargado del Registro civil o ante quien pueda dar fe de la misma -fedatario público-» ( gistro civil (Estudio sistemático de la reforma introducida por la Ley 11/1981, de 13 de mayo en el Código civil)», en BIMJ, n. 1274, 5 de mayo, Madrid, 1982, pág. 7).

${ }_{55}$ Op. cit., pág. 223.

56 «Comentario a los artículos..., op. cit., pág. 870. También MARTÍNEZ-CALCERRADA GÓMEZ sostiene que «podrá realizarse en documento público o privado u otro artificio que es lo aconsejable» [El nuevo Derecho de familia. II. (Régimen sobre Filiación y Sociedad de Gananciales) -Teoría, norma y práctica- Análisis de la Ley de 13 de mayo de 1981, Graficas Espejo, Madrid, 1981, pág. 60].

57 «La filiación», $R D N$, CXX, abril-junio, 2-1983, pág. 302. También, DÍEZ-PICAZO 
cerse ante el encargado del Registro Civil o en escritura pública, ya que de lo contrario no podría revestir ninguna garantía de que la declaración proceda del marido. Además no se le puede obligar a éste para que realice la declaración ante el encargado del Registro Civil, pues tal exigencia no se contiene en el artículo 117». Según BLASCO GASCÓ ${ }^{58}$ la declaración auténtica «tiene que realizarse expresamente en escritura pública».

Siguiendo a RIVERO HERNÁNDEZ ${ }^{59}$, conviene precisar que la declaración auténtica se ha de formalizar ante el encargado del Registro Civil, que deberá incorporarla al acta de nacimiento del hijo en cuestión, lo que se justifica en la posible autenticidad que persigue el esposo, al querer dejar constancia notarial de su declaración, siendo insuficiente realizarla sin ulteriores requisitos ante notario.

En la actualidad, el Código civil de Cataluña ${ }^{60}$ también prevé la autenticidad de la declaración y su entrada en el Registro civil, por lo que se equipara con lo preceptuado por el artículo 117 del Código civil y lo establecido en el Reglamento del Registro civil.

Dos son los tipos de declaración que establece el artículo 117 del Código civil, de una parte, la declaración unilateral en la que el esposo deberá manifestar su no paternidad ${ }^{61}$-criterio subjetivo- $\mathrm{y}$, de otra, la bilateral de ambos cónyuges, cuando el esposo hubiese co-

y GULLÓN BALLESTEROS entiende que la declaración autentica es «sinónima de declaración verdadera y fidedigna [...]. Por eso entendemos que lo pretendido es que la declaración se haga bajo una forma que garantice su autenticidad (v. gr., escritura pública, ante el encargado del Registro Civil» (Instituciones de Derecho..., op. cit., págs. 255-256). Y, vid., LACRUZ BERDEJO Y SANCHO REBULLIDA: Elementos de Derecho civil. IV. Derecho de Familia, Ed. Experimental Librería Bosch, Barcelona, 1982, págs. 625 y ss.; PUIG BRUTAU, op. cit., págs. 195 y ss.

58 «La filiación»..., op. cit., pág. 383.

59 Elementos del Derecho Civil..., op. cit., pág. 76.

60 «Artículo 235-6. 1. Si el hijo nace dentro de los ciento ochenta días siguientes a la celebración del matrimonio, el marido puede dejar sin efecto la determinación de la filiación que resulta del artículo 235-5 declarando que desconoce su paternidad. Esta declaración, que debe ser auténtica, debe entrar en el Registro Civil en el plazo de los seis meses siguientes al nacimiento».

${ }^{61}$ Vid., RIVERO HERNÁNDEZ: «El desconocimiento de la paternidad del hijo nacido dentro de los ciento ochenta días siguientes al matrimonio", en RJNav, Homenaje al profesor SANCHO REBULLIDA, enero-junio, n. 15, 1993, pág. 280. Por el contrario, CÁMARA ÁLVAREZ dice que «lo razonable es exigir que, al inscribir esa declaración, se justifique de algún modo que el marido desconocía al casarse el embarazo de su mujer y no reconoció expresamente al hijo o realizó algún acto que pueda calificarse de reconocimiento tácito» (Comentarios al Código Civil..., op. cit., pág. 218). Es de la misma opinión, SERNA MEROÑO: La reforma de la filiación, Montecorvo, Madrid, 1985, págs. 216 y ss. 
nocido del embarazo de su mujer antes de contraer matrimonio, en la que el cómputo del plazo se realizará desde el nacimiento o parto -criterio objetivo-. Esta declaración conjunta reunirá las formalidades establecidas para la declaración unilateral del esposo ${ }^{62}$.

Por declaración unilateral, se entiende la realizada por el esposo, el cual dispondrá de un plazo de seis meses que se computará desde el conocimiento del parto, para ejercitar la acción de desconocimiento, siendo el ‘dies a quo〉 el día siguiente a aquél en el que éste conoce el nacimiento ${ }^{63}$.

Sin embargo, el Código civil de Cataluña, establece que para poder ejercitar la declaración de desconocimiento, ésta se deberá producir en los seis meses siguientes al nacimiento, con la finalidad de evitar conflictos en la determinación del momento en el que el padre conoce el nacimiento del hijo que se le atribuye por Ley. Empero, comporta el riesgo derivado de la hipotética ignorancia del marido sobre la fecha del parto, en el supuesto de una separación de hecho inmediatamente posterior a la celebración del matrimonio; ello obligaría, en su caso, a ejecutar una acción de impugnación.

Conforme al inciso primero del artículo 117 del Código civil, la doctrina se plantea qué se debe entender por parto. Para RIVERO HERNÁNDEZ ${ }^{64}$ es «la noticia cierta que debe tener el marido del hijo tenido por su esposa, cualquiera que sea la fuente de su conocimiento».

Pese a lo anterior, la mera noticia del nacimiento, sin que ésta vaya acompañada de la fecha exacta del aquél, no debería ser suficiente, toda vez que podría aparejar ciertos errores, lo que se justifica en la posible ausencia prolongada por circunstancias del marido al poco tiempo de contraer nupcias. Este sería el caso de una separación de hecho a los pocos de días de haber contraído matrimonio los cónyuges, en el que habiéndose consumado aquél y producido la separación conyugal sin que el esposo supiese del estado de gestación de su mujer -puesto que si fuese sabedor y el hecho demostrable, no sería suficiente su simple declaración, sino que sería necesaria la concurrencia de la declaración de la esposa-, transcurrido un tiempo le hubiesen llegado noticias de que aquélla tuvo un hijo. Supuesto en el que, al desconocer la fecha exacta del nacimiento, lógicamente, no

62 Vid., GARCÍA CANTERO: «La filiación», en Derecho Civil español, Común y Foral. IV. Derecho de Familia, Relaciones paternofiliales y tutelares, Vol. II, de José Castán Tobeñas, Reus, Madrid, 1985, 9. ${ }^{a}$ edición revisada y puesta al día, pág. 109.

${ }^{63}$ Vid., RIVERO HERNÁNDEZ: «El desconocimiento de la paternidad..., op. cit., pág. 281.

${ }^{64}$ Ibídem. 
sabrá si su concepción se realizó durante el tiempo que duró su matrimonio o con posterioridad a su ausencia.

En esta situación podrá suceder:

a) La posibilidad de averiguar la fecha exacta del nacimiento del hijo, si se lo comunica la madre o los familiares. Supuesto en el que únicamente a partir de entonces podría tener cierta certeza sobre su propia paternidad. En caso de que hubiera nacido dentro de los ciento ochenta días siguientes a la celebración del matrimonio, podrá realizar, desde que haya tenido conocimiento de la fecha del nacimiento y durante seis meses, la acción de desconocimiento.

b) La imposibilidad de averiguar la fecha del nacimiento del hijo, por desconocimiento del paradero de la madre y del hijo concebido por ella. Caso en el que no sabrá si el hijo es suyo quedándole vedada, tanto la acción de desconocimiento como la de impugnación [arts. 136 y $137 \mathrm{CC}]$ y, por tanto, el esposo desconocerá si el hijo ha nacido dentro de los ciento ochenta días o con posterioridad y, si es fruto de una gestación normal. Por ello, las noticias sobre el nacimiento del hijo deberán estar acompañadas de la fecha de su nacimiento, para que tenga la posibilidad de ejercitar -si procede- la acción de desconocimiento si el nacimiento ha tenido lugar dentro de los ciento ochenta días siguientes a la celebración del matrimonio.

En suma, el Código civil prevé que la declaración debe acceder al registro en un periodo máximo de seis meses desde el conocimiento del parto [art. $117 \mathrm{CC}$ ], mientras que el Código civil de Cataluña establece que el plazo se computará, tanto en caso de declaración unilateral como en caso de declaración bilateral de los cónyuges, a partir del nacimiento del hijo y no del conocimiento del parto, por lo que establece a favor del hijo un criterio objetivo ${ }^{65}$.

Asimismo, el artículo 117 del Código civil establece dos plazos -con un periodo de seis meses- para destruir la presunción de paternidad. De una parte, desde el conocimiento del parto -primer inciso del art. 117 CC- que, posiblemente, indica el momento en el que el esposo se da cuenta del parto, debido a que en realidad no tiene porqué conocer del estado de gestación de su esposa; De otra, desde el conocimiento del nacimiento o parto -segundo inciso del art. $117 \mathrm{CC}-$ en el que lógico es pensar que el esposo ya era sabedor del estado de gestación de la esposa lo que comporta el conocimiento del parto ${ }^{66}$.

${ }^{65}$ Cfr., artículo 235-6.1 del Código civil de Cataluña.

${ }^{66}$ Vid., CORDERO CUTILLAS, «Presunción de Paternidad..., op. cit., pág. 207. 
De lo anterior, cabe deducir que todo hombre que contrae matrimonio con una mujer embarazada, es porque o bien cree en ese momento que el hijo es suyo o, porque desea asumir los deberes paternofiliales, puesto que en caso contrario, lo normal es que lo manifieste con anterioridad a la celebración de las nupcias.

Pese a ello, podría suceder que se inscribiera al hijo como matrimonial, cuando la madre no hubiese formulado la correspondiente declaración en contrario a posteriori. No suponiendo el conocimiento del embarazo anterior a la celebración del matrimonio un reconocimiento tácito, ya que con este conocimiento no se asume la paternidad del menor ${ }^{67}$.

En este caso, el encargado del Registro lo inscribirá como matrimonial, basándose en el conocimiento del embarazo, salvo que concurra la declaración de la madre asintiendo la no paternidad. Así, por ejemplo, si el hijo hubiera nacido dentro de los ciento ochenta días siguientes a la celebración del matrimonio y el padre no quisiera aceptar su paternidad ante el encargado del Registro civil, éste deberá proceder a realizar cuantas indagaciones estime oportunas, al objeto de averiguar si ha existido un previo reconocimiento por el esposo o, si éste era sabedor del embarazo de su mujer con anterioridad al matrimonio ${ }^{68}$. Supuesto en el que si el esposo afirma que era sabedor del estado de gestación de su mujer, pero que no asumió la paternidad, debido a que tenía la certeza de que el menor se inscribiría como hijo no matrimonial -por manifestación de su esposa-, el encargado del Registro deberá inscribirlo como matrimonial [segundo inciso del art. 117 CC] denegando, por tanto, su solicitud y debiendo el esposo acudir a la vía judicial, ya que en caso contrario, se presume que reconocerá de forma tácita su paternidad.

\section{A) Excepciones}

En cuanto a las excepciones del artículo 117 del Código civil, conviene precisar que el esposo no podrá desconocer la paternidad mediante la declaración auténtica en contrario, si hubiese reconocido la paternidad expresa o tácitamente o, conocido el embarazo de la mujer

${ }^{67}$ Vid., IBÍDEM.

${ }^{68}$ En este punto, LLEDO YAGÜE dice que «el padre podrá refutar su paternidad, bien incoando un expediente de desconocimiento ante el juez encargado del Registro civil, o bien, mediante una declaración auténtica, fehaciente o no, de denegación de paternidad» (op. cit., pág. 157). 
con anterioridad a la celebración del matrimonio ${ }^{69}$, salvo que en este último supuesto, la declaración autentica se haya formalizado, con el consentimiento de ambos, con anterioridad o posterioridad del matrimonio, dentro de los seis meses siguientes al nacimiento del menor.

En este mismo sentido, se pronuncia el Código civil de Cataluña, puesto que en su artículo 235-6 prevé que: «2. El desconocimiento de la paternidad no es eficaz en los siguientes casos: a) Si el marido ha conocido el embarazo antes de contraer matrimonio, salvo que la declaración a que se refiere el apartado 1 se haya hecho con el consentimiento de la mujer. b) Si el marido ha admitido la paternidad de cualquier forma. c) Si la madre demuestra la existencia de relaciones sexuales con el marido durante el período legal de la concepción».

Supuestos todos como RIVERO HERNÁNDEZ ${ }^{70}$ indica -con acierto- cuya finalidad es invalidar o hacer ineficaz el desconocimiento del padre ${ }^{71}$, ya que si dicho reconocimiento se impugna como vicio del consentimiento, deja la vía «expedita para que pueda tener lugar la declaración auténtica destinada a destruir la presunción de paternidad $\gg^{72} \mathrm{y}$, por tanto, si al promover la inscripción el esposo presenta la declaración de desconocimiento alegando que el nacimiento se ha producido en el plazo de los ciento ochenta días, será necesario que el encargado del Registro realice cuantas averiguaciones sean suficientes, en un plazo determinado - diez días-, para averiguar si se ha producido o no un reconocimiento previo ${ }^{73}$.

${ }^{69}$ Por cuanto atañe a esta segunda excepción, LASARTE ÁLVAREZ sostiene que la necesidad de que la declaración auténtica se realice conjuntamente por las partes, radica en que al ser el embarazo anterior al matrimonio y, por tanto, en realidad el futuro marido todavía no lo es, no debería de imputársele presunción de paternidad alguna. Sin embargo, añade este autor, que «realmente el Código sigue presumiendo que el futuro o subsiguiente matrimonio es precisamente una constatación de que la paternidad corresponde al varón que, conociendo previamente el hecho, contrae matrimonio con la mujer que ya se encuentra embarazada» (Principios del Derecho Civil, Derecho de Familia, T. VI, Marcial Pons, Madrid, 2011, 10. ${ }^{a}$ ed., pág. 291). Vid., también las aportaciones de DÍAZ-AMBRONA BARDAJÍ y HERNÁNDEZ GIL: Lecciones de Derecho de Familia, Centro de Estudios Ramón Areces S.A., Madrid, 1999, pág. 339.

${ }^{70}$ «El desconocimiento de la paternidad..., op. cit., pág. 282. Por el contrario, GARCÍA ZARANDIETA, entiende que «entonces la paternidad queda determinada por medios ajenos a la presunción, de forma que se iría contra el carácter irrevocable del reconocimiento [art. $741 \mathrm{CC}$ ]-» («La filiación y el Registro civil (Estudio sistemático de la reforma introducida por la Ley 11/1981, de 13 de mayo en el Código civil)», en $B I M J$, n. 1272, 15 de abril, Madrid, 1982, pág. 9).

${ }^{71}$ En este punto, MARTÍNEZ CALCERRADA, indica que «la excepción se encuentra amparada en la teoría de los actos propios» (op. cit., pág. 61).

72 Vid., QUESADA GONZÁLEZ, op. cit., pág. 165.

73 Dice la Ley del Registro civil en su «artículo 28: Inmediatamente de formularse las declaraciones o de ser presentados los documentos necesarios, el encargado del 
Sin embargo, la madre será quien tenga que demostrarlo y sólo en caso de que no se pueda probar el reconocimiento, ni expreso, ni tácito, se tendrá que acudir a la vía judicial para reclamar la paternidad matrimonial ${ }^{74}$. Lo que evidentemente contrasta con lo previsto por el Código civil de Cataluña, debido a que hace ineficaz la declaración de desconocimiento realizada por el esposo respecto del menor que nace dentro de los ciento ochenta días, cuando la madre demuestre que tuvo relaciones sexuales con su esposo durante el periodo legal de la concepción [art. 235-6.2 c) ${ }^{75}$ CCCat.]. Asimismo, en su artículo 235-4 prevé que: «El período legal de concepción comprende los primeros ciento veinte días del período de gestación, que se presume de un máximo de trescientos días, salvo que pruebas concluyentes demuestren que el período de gestación ha durado más de trescientos días».

Finalmente, respecto del reconocimiento expreso aludido por el precepto, conviene matizar que podrá ser verbal -el cual presentará como problema la prueba- o, escrito -documento público o privado- ${ }^{76}$.

\section{B) Capacidad}

Por lo que a la capacidad para prestar el reconocimiento se refiere, entre otros, RIVERO HERNÁNDEZ ${ }^{77}$ establece que el reconocimiento no afecta a la determinación de la paternidad, como ocurre en la filiación extramatrimonial, sino únicamente a efectos de invalidar el desconocimiento. Por su parte, CORDERO CUTILLAS -con acierto- sostiene que el reconocimiento aunque tiene como objeto invalidar el desconocimiento, también determina la paternidad.

Cierto es que el reconocimiento -expreso o tácito-, supone la afirmación de su propia paternidad, debido a que si el padre lo realiza es porque que considera que el hijo es suyo y, por tanto, si tuviese la creencia de que no lo es o pensase que no tiene cabida por las circunstancias que fuesen, posiblemente, no lo habría reconocido. Esto se

\footnotetext{
Registro extenderá los asientos o dictará resolución razonada denegándolos. Si tuviere dudas fundadas sobre la exactitud de aquellas declaraciones, realizará antes de extenderlas, y en el plazo de diez días, las comprobaciones oportunas».

${ }^{74}$ En este sentido, vid., la Resolución de la DGRN de 5 de marzo de 1994.

75 Cfr., artículo 235-6. 2. del Código civil de Cataluña.

76 Vid., RIVERO HERNÁNDEZ, «El desconocimiento de la paternidad..., op. cit., pág. 284.

77 «El desconocimiento de la paternidad..., op. cit., pág. 283.
} 
justifica en el artículo 117 del Código civil, debido a que admite dos formas de reconocimiento -el expreso y el tácito-, mientras que para reconocer a un hijo extramatrimonial es necesario que el reconocimiento se realice ante el encargado del Registro civil -en testamento o en otro documento público-, pero no admite el reconocimiento tácito.

En síntesis, dos son las causas por las que no será posible que los requisitos que son exigidos en el reconocimiento de filiación matrimonial sean los mismos que en el de filiación extramatrimonial. Son, de una parte, porque admite el reconocimiento tácito y, de otra, porque la paternidad está amparada por la presunción, debido a que al existir ésta el reconocimiento no será tan exhaustivo, como el exigido en el ámbito extramatrimonial.

Otra cuestión se centra en el supuesto de que el presunto padre fuese un menor de edad -catorce años-y el reconocimiento se hubiese efectuado antes de contraer matrimonio. En este caso será necesaria, en principio, la aprobación judicial [art. $121^{78} \mathrm{CC}$ ]. Y si el matrimonio se llevase a término, indudablemente, se justificará en la obtención de la dispensa de edad prevista por el artículo $48.2^{79}$. Sin embargo, conviene tener presente que cualquier reconocimiento anterior a la solicitud de la dispensa matrimonial será difícil. Por tanto, si se realiza el reconocimiento expreso antes de la dispensa matrimonial alegando como justa causa en la solicitud de la dispensa de edad cualquier otra causa que no sea el embarazo de su novia, para que opere como consentimiento expreso será necesaria la aprobación judicial, no ocurriendo así en el reconocimiento tácito ${ }^{80}$.

Esta solución también será de aplicación si el presunto padre es una persona incapaz, sin embargo, habrá de estar a lo que disponga la sentencia de incapacitación, de acuerdo con la Ley de Enjuiciamiento Civil, y si ésta no dispusiera nada al efecto, necesitará de la anuencia judicial.

78 «El reconocimiento otorgado por incapaces o por quienes no puedan contraer matrimonio por razón de edad necesitará para su validez aprobación judicial con audiencia del Ministerio Fiscal».

79 «2. El Juez de Primera Instancia podrá dispensar, con justa causa y a instancia de parte, los impedimentos del grado tercero entre colaterales y de edad a partir de catorce años. En los expedientes de dispensa de edad deberán ser oídos el menor y sus padres o guardadores».

${ }^{80}$ En este sentido, vid., las argumentaciones de CORDERO CUTILLAS, «Presunción de Paternidad..., op. cit., págs. 208 y ss. 


\section{2) Disolución y Separación de Hecho o de Derecho de los cónyuges: cuestiones sobre el cómputo del plazo}

Como se ha dicho, el artículo 116 del Código civil, establece que «se presumirán hijos del marido los nacidos después de la celebración del matrimonio y antes de los trescientos días siguientes a su disolución o a la separación legal o de hecho de los cónyuges».

Del tenor literal del precepto y de la referencia a «antes de`, cabe deducir que el día trescientos ya no opera ${ }^{81}$, por lo que la concepción se presume matrimonial, sea de hecho o de Derecho.

En este sentido, el Código civil de Cataluña amplía los efectos de la presunción a los nacidos más allá de los trescientos días siguientes a la disolución del matrimonio, siempre que se acredite cumplidamente y mediante toda clase de pruebas que nacieron de relaciones conyugales $^{82}$.

Una de las novedades más importantes introducidas por el legislador en el precepto, ha sido la situación de la separación de hecho. En este caso, subsiste el vínculo matrimonial y, en consecuencia, el fundamento de la presunción no se encuentra en el matrimonio en sí, sino en la convivencia conyugal mantenida durante el periodo de la concepción $^{83}$. Convivencia que ha dado origen a numerosas controversias doctrinales. Así, parte de la doctrina ${ }^{84}$ sostiene que su cese efectivo para realizar un procedimiento de separación o divorcio no se puede trasladar al ámbito de la filiación, por el contrario otro sec-

${ }^{81}$ Así, CÁMARA ÁLVAREZ sostiene que «la tesis de permitir la inscripción del nacimiento del menor, justificando el parto ante el encargado del Registro, por medio de la aportación de un dictamen pericial» (Comentarios al Código Civil..., op. cit., pág. 232). Este autor, hace una interpretación extensiva del artículo 118 del Código civil, aplicándolo por analogía. Por el contrario, PEÑA BERNALDO DE QUIRÓS manifiesta que «deberá acudirse a una acción de reclamación para demostrar la paternidad» («Comentario a los artículos..., op. cit., pág. 878). Vid., también en idéntico sentido, las aportaciones de PUIG BRUTAU, op. cit., pág. 195; RODRÍGUEZ ADRADOS, op. cit., pág. 290; RIVERO HERNÁNDEZ, Elementos del Derecho Civil..., op. cit., pág. 73.

82 «Artículo 235-5.2. Los hijos nacidos después de los trescientos días siguientes a la separación judicial o de hecho de los cónyuges son matrimoniales si se prueba que han nacido a consecuencia de las relaciones sexuales entre los cónyuges. La misma regla se aplica en el caso de nulidad o de disolución del matrimonio si se prueba que las relaciones han tenido lugar antes de producirse estos efectos».

${ }^{83} \mathrm{Vid}$., en este sentido, entre otros, CORDERO CUTILLAS, "Presunción de Paternidad..., op. cit., pág. 210; PEÑA BERNALDO DE QUIRÓS, «Comentario a los artículos..., op. cit., pág. 867.

${ }^{84}$ Vid., FÉREZ FERNÁNDEZ Y GARRIGA GORINA, op. cit., pág. 1070. 
tor de la literatura jurídica ${ }^{85}$ afirma que se pueden trasladar los conceptos de separación de hecho del ámbito matrimonial al de la filiación, aunque matizan que cuestión distinta será la de la prueba que verifique la separación de hecho.

En este sentido, CORDERO CUTILLAS ${ }^{86}$ distingue los siguientes supuestos: De una parte, que la separación se encuentre constatada -por documento notarial o por sentencia de separación o divorcio- y que establezca la fecha de la previa separación de hecho de los cónyuges. Situación en la que si hubiese oposición por el esposo, aunque la madre manifieste la existencia de tales relaciones esporádicas durante la separación de hecho, el hijo deberá inscribirse como hijo no matrimonial de la madre, puesto que la presunción marital en este caso sería inoperante -de acuerdo con los artículo 116 del Código civil y el artículo 185 del RRC, los cuales facultan la inscripción de la paternidad de otro hombre, si se comprueba antes de la inscripción que no rige la presunción legal de paternidad-. En suma, la presunción no existirá, debido a que la separación de hecho se encuentra acreditada en un documento público y, en consecuencia, la madre deberá demostrar la existencia de relaciones con su esposo durante el periodo de separación de hecho en un procedimiento judicial y reclamar la paternidad patrimonial.

De otra, el supuesto en el que la separación de hecho no se encuentre constatada. En este caso el encargado del Registro Civil denegará la inscripción extramatrimonial de la mujer casada, si no llega a la convicción de que no rige la presunción de paternidad. Asimismo, podrá considerar que tales relaciones esporádicas imposibilitan la separación de hecho y, por tanto, en caso de duda sobre la fecha inicial de la separación, el menor será inscrito como hijo matrimonial y el padre deberá acudir a la vía judicial para refutar su paternidad si tuviera el convencimiento de que el menor no es hijo suyo $^{87}$.

Conviene puntualizar que todo estará en función de la prueba que verifique la separación de hecho, siendo ésta sencilla si se encuentra documentada y, por tanto, aunque en principio todo apunte a que la simple declaración formulada dentro de plazo será suficiente para excluir la filiación paterna, lo cierto es que no lo es, ya que du-

85 Vid., CORDERO CUTILLAS, La impugnación de la paternidad..., op. cit., pág. 36.

${ }^{86}$ La impugnación de la paternidad..., op. cit., pág. 37.

87 Ibídem. 
rante dicha situación la presunción de convivencia sigue presente aunque tengan distintos domicilios ${ }^{88}$.

Por ello, el encargado del Registro civil deberá realizar las averiguaciones que estime oportunas en el plazo de diez días, con audiencia de los cónyuges o de sus herederos si fuera posible, requiriéndose para excluir la presunción de paternidad de una demostración más certera. En este sentido, la Resolución de la Dirección General de los Registros del Notariado, de 2 de agosto de 1991 afirma que, dicha presunción «no puede quedar sin efecto por simples declaraciones de los particulares, sino que se ha de justificar por otros medios el «dies a quo〉 de la separación ${ }^{89}$.

Por su parte, en la Resolución de la Dirección General de los Registros del Notariado, de 30 de noviembre de 1995, aun a pesar de la declaración unánime de ambos cónyuges de que el hijo no era del marido, se inscribió la filiación matrimonial, aunque en realidad ya no operaba la presunción de paternidad, siendo en principio extramatrimonial: «En el supuesto, a la vista de las declaraciones de ambos cónyuges, hay que concluir que el nacimiento ha acaecido cuando aún no habían transcurrido trescientos días desde la separación de hecho. Rige, pues, la presunción de paternidad del marido, corroborada por la de convivencia entre los cónyuges [art. $69 \mathrm{CC}$ ], que tiene valor probatorio de la filiación presumida [art. $113 \mathrm{CC}$ ], y la cual no ha sido desvirtuada. Si los cónyuges vivían bajo el mismo techo, no es posible en este ámbito registral estimar la separación de hecho de la comunidad de vida conyugal, a diferencia de lo que puede ocurrir en otros ámbitos [art. $87 \mathrm{CC}$ ], porque esta solución dejaría al libre arbitrio de los cónyuges decidir el carácter de la filiación, lo que no ha de obstar para que por la vía judicial oportuna pueda impugnarse por los legitimados al efecto la paternidad discutida ${ }^{90}$.

88 Vid., en este sentido, las Resoluciones de la DGRN de 18 de noviembre de 1996 (RJ 1997, 6907) y de 19 de octubre de 1996 (RJ 1997, 3570). Ambas tienen como denominador común que -en ningún momento- ni se prueba la separación de hecho durante los trescientos días que preceden al nacimiento del hijo, ni la falta de convivencia entre los cónyuges, debido a que se presume, salvo prueba en contrario, que los cónyuges viven juntos [art. $69 \mathrm{CC}$ y en ambas la simple oposición de uno de ellos a la inscripción no evita la inscripción matrimonial de la menor.

${ }^{9}$ (RJ 1991, 6304). Vid., en el mismo sentido, la Resolución DGRN 22 de mayo de 1991, recogida por FÉREZ FERNÁNDEZ y GARRIGA GORINA, op. cit., págs. 10651076.

${ }^{90}$ (RJ 1996, 1400) y, vid., las Resoluciones de la DGRN de 26 de junio de 1992 (La Ley: 9449/1992) y, de 22 de mayo de 1991, recogida por FÉREZ FERNÁNDEZ y GARRIGA GORINA, op. cit., págs. 1065-1076. 
Sin embargo, si el medio de prueba es la falta de posesión de estado $^{91}$, nada impide que se pueda inscribir como matrimonial por aplicación del artículo $118^{92}$ del Código civil y, por tanto, el legislador ha establecido que el hijo aunque sea extramatrimonial -porque ya no opera la presunción- se pueda inscribir como matrimonial, sin tener que ejercitar una acción de reclamación ${ }^{93}$.

Por cuanto atañe al consentimiento, conviene precisar que éste presenta un doble significado, es decir, que si procede del esposo hará referencia a reconocimiento ${ }^{94}$, mientras que si procede de la madre supondrá la conformidad en la atribución de la paternidad, debido a que como proviene de relaciones sexuales voluntarias, será la madre quien tendrá la constancia de la posible existencia o no de otras relaciones ${ }^{95}$.

Asimismo, el Código civil no establece nada sobre la forma y el plazo del consentimiento. Así, RIVERO HERNÁNDEZ ${ }^{96}$ afirma que «la forma podrá ser libre, pública o privada, aunque lo normal es que se haga por comparecencia ante el Registro». Por su parte, PEÑA BERNALDO DE QUIRÓS ${ }^{97}$ manifiesta que «se puede realizar de

91 En este sentido, vid., la Resolución de la DGRN de 11 de octubre de 1991 (La Ley: 9286/1991), donde así quedó reflejado. Por el contrario, en la Resolución de la DGRN de 22 de noviembre de 1994 (La Ley: 12484/1994) se estableció que hay que probar en el expediente registral que o entra en juego, a causa de la separación de los cónyuges, la presunción de paternidad del marido. Mientras que las alegaciones sobre que éste no es el padre quedan reservadas a la vía judicial en el ejercicio de la oportuna acción de impugnación. En el mismo sentido, la Resolución de la DGRN de 22 de mayo de 1992 (La Ley: 8334/1992) estableció que hay que probar la previa separación de hecho y su existencia [art. $69 \mathrm{CC}$ ]. No vale como medio de prueba la alegación de la esterilidad del marido, esta alegación sirve en el juicio correspondiente.

92 «-Aun faltando la presunción de paternidad del marido por causa de la separación legal o de hecho de los cónyuges, podrá inscribirse la filiación como matrimonial si concurre el consentimiento de ambos»

${ }_{93}$ Vid., RIVERO HERNÁNDEZ, Elementos del Derecho Civil..., op. cit., pág. 79.

94 Así, vid., entre otros, CÁMARA ÁLVAREZ, Comentarios al Código Civil..., op. cit., pág. 233; PEÑA BERNALDO DE QUIRÓS, «Comentario a los artículos..., op. cit., pág. 878; GARCÍA CANTERO, op. cit., pág. 116.

${ }_{95}$ En este sentido, PEÑA BERNALDO DE QUIRÓs dice que «la voluntad de los cónyuges, no es valorada como una materia sujeta a la autonomía de la voluntad (ya que es indiferente el estado civil), sino porque tal expresión de la voluntad es signo suficiente de la verdad biológica (referido a la filiación no matrimonial)» («Comentario a los artículos..., op. cit., pág. 878). Vid., también las aportaciones de RIVERO HERNÁNDEZ, Elementos del Derecho Civil..., op. cit., pág. 79.

${ }^{96}$ Elementos del derecho civil..., op. cit., pág. 79.

97 «Comentario a los artículos 108 a 141 del Código civil (De la paternidad y filiación)», en Comentarios a las Reformas del Derecho de Familia, Vol. I, Tecnos, Madrid, 1984, pág. 879. 
cualquier forma, y en cualquier momento, es decir, incluso antes del nacimiento».

Por lo que al plazo se refiere, el párrafo segundo del artículo 113 del Código civil establece, que: "No será eficaz la determinación de una filiación en tanto resulte acreditada otra contradictoria».

Por otra parte, en caso de que al nacimiento hayan precedido trescientos días siguientes a una sentencia de divorcio, el hijo será extramatrimonial no resultando conforme al artículo 118 del Código civil que sea matrimonial, salvo en caso de que proceda de relaciones conyugales.

En este sentido, PEÑA BERNALDO DE QUIRÓS ${ }^{98}$ aprecia que «en los casos de disolución del matrimonio la Ley no dice que se presuman no matrimoniales, sino solamente que no se presuman matrimoniales los hijos nacidos mas allá de los trescientos días siguientes a la disolución o a la declaración de nulidad». Por su parte, CÁMARA ÁLVAREZ ${ }^{99}$, afirma que "sería menester que el nacimiento haya acaecido muy pocos días después de la firmeza de la sentencia de divorcio y que se aporte un dictamen médico solvente que acredite la duración anormalmente prolongada del embarazo». En este punto, se puede sostener que será necesario aportar además del mencionado dictamen médico acreditativo de la duración del embarazo, el resultado de la prueba biológica que acredite la paternidad biológica -ya que ambas partes están de acuerdo-.

Otro punto de interés es el relativo a las dos cuestiones suscitadas, de una parte, si el hijo fuera fruto de una relación extramatrimonial y los ex cónyuges estuvieran de acuerdo sobre la filiación paterna del ex marido. Cuestión que se salva al amparo de lo establecido por el artículo 120 del Código civil y, de otra, en el supuesto de que hubiera acaecido el fallecimiento del esposo, indudablemente, el hijo será extramatrimonial, debido a que no tendrá cabida la aplicación analógica del artículo 118 del Código civil, puesto que el precepto es de aplicación, únicamente, a los casos de separación legal o de hecho. Además, se debe tener presente la necesidad del consentimiento de ambas partes -consentimiento del esposo difícil de obtener, puesto que ha fallecido- y la imposibilidad de dejarlo al arbitrio de sus herederos, puesto que el reconocimiento es de carácter personalísimo.

98 Derecho de Familia. Servicio de publicaciones, Facultad de Derecho Universidad Complutense, Madrid, 1989, págs. 418 y ss.

99 Comentarios al Código Civil..., op. cit., pág. 236. 
En este sentido, CORDERO CUTILLAS ${ }^{100}$-con acierto-, aboga por la aplicación de los artículos $115^{101}$ y párrafo primero del $113^{102}$ del Código civil, en relación con los artículos 2 y párrafo segundo del artículo 49 de la Ley del Registro Civil, es decir, por la posesión de estado, como medio para acreditar la filiación matrimonial en el expediente de inscripción fuera de plazo. Otro sector doctrinal ${ }^{103}$, sostiene que el artículo 113 no diferencia entre filiación matrimonial y no matrimonial, por lo que la posesión de estado sería un medio para la acreditación de la filiación a falta de otros.

Asimismo, en el presente caso se observa que, de una parte, faltaría la inscripción, debido a que lo que se pretende es inscribir la filiación acreditando en el expediente la posesión de estado, de otra, el documento o sentencia que la determine legalmente, puesto que el padre no lo ha reconocido y, finalmente, la presunción de paternidad, ya que el hijo ha nacido transcurridos los trescientos días [art. 116 $\mathrm{CC}$ ] que precedieron al fallecimiento del padre. Y, por tanto, la inexistencia de los datos descritos justifica que la posesión de estado -cuando pueda probarse en el expediente- acredite la filiación a los efectos de los artículos 115 y del párrafo primero del artículo 113 del Código civil.

Por otra parte, en caso de que el esposo no hubiera tenido constancia del embarazo de su esposa, los actos de sus familiares serán suficientes frente a la imposibilidad de ser ejercitados por aquél -debido a su fallecimiento-, cuando no hubiera oposición y todos los familiares estuviesen de acuerdo.

Finalmente, en caso de inscripción por la madre de la filiación del hijo como matrimonial, conviene precisar la falta de exigencia de que el padre acuda a la vía judicial con la finalidad de impugnar su paternidad. Esto se justifica en el hecho de que si el hijo ha nacido más allá de los trescientos días que prevé el artículo 116 del Código civil tras el fallecimiento el padre o la sentencia de divorcio o sepa-

${ }^{100}$ La impugnación de la paternidad..., op. cit., pág. 39.

101 «La filiación matrimonial materna y paterna quedará determinada legalmente: 1. Por la inscripción del nacimiento junto con la del matrimonio de los padres. 2. Por sentencia firme».

102 «La filiación se acredita por la inscripción en el Registro Civil, por el documento o sentencia que la determina legalmente, por la presunción de paternidad matrimonial y, a falta de los medios anteriores, por la posesión de estado. Para la admisión de pruebas distintas a la inscripción se estará a lo dispuesto en la Ley de Registro Civil».

${ }^{103} \mathrm{Vid}$., PEÑA BERNALDO DE QUIRÓS, «Comentario a los artículos..., op. cit., pág. 840; CÁMARA ÁLVAREZ, Comentarios al Código Civil..., op. cit., pág. 160. 
ración legal, los herederos o éste podrán solicitar la rectificación del Registro mediante expediente gubernativo [art. 93.3104 LRC].

De lo dicho, se puede concluir la afirmación de que la inscripción de defunción o de la sentencia de separación o divorcio dará fe de la fecha en que los acontecimientos hubieran tenido lugar y, por tanto, se podrá rectificar la inscripción de la filiación.

Por último, dos son los supuestos suscitados por la separación de hecho:

- Que la separación de hecho se haya acreditado documentalmente por escritura notarial, en la que las partes de común acuerdo establezcan su separación -física yo económica-. En este supuesto el documento será objeto de inscripción, corrigiéndose a través de ésta la filiación por medio de expediente gubernativo.

- Que no exista prueba documental de la fecha de separación. Caso en el que no se podrá modificar la inscripción por expediente gubernativo y, por tanto, será necesario recurrir a la vía judicial.

En cuanto a los plazos, y si bien estarán en función del tema objeto de litigio y, respecto de las causas de la disolución, éstas se encuentran establecidas en el artículo 85 del Código civil: la muerte; declaración de fallecimiento de uno de los cónyuges y el divorcio.

Por lo que atañe al supuesto de muerte, el plazo de los trescientos días correrá desde aquel momento en que el óbito tenga lugar ${ }^{105}$. Mientras que en el de declaración de fallecimiento, será desde la fe-

104 «3. Cualquier otro error cuya evidencia resulte de la confrontación con otra u otras inscripciones que hagan fe del hecho correspondiente».

${ }^{105}$ En caso de que el nacimiento se produjera después de los trescientos días al fallecimiento, CÁMARA ÁLVAREZ sostiene que «sería conveniente aplicar por analogía el artículo 118 del Código civil en lugar de acudir a la acción de reclamación de la filiación matrimonial, es decir, inscribir la filiación matrimonial por medio del consentimiento de ambos cónyuges. Consentimiento que sería suplido por el de la madre o los herederos del marido» (Comentarios al Código Civil..., op. cit., pág. 234). Por el contrario, POZO VILCHES entiende -con acierto- que "dicho precepto no puede ser de aplicación por fallecimiento en el caso indicado, ya que no está prevista ni expresa, ni tácitamente la disolución por fallecimiento del marido; solo admite el consentimiento conjunto en caso de separación legal o de hecho de los cónyuges. No es lo mismo que el consentimiento sea prestado por el marido que no es más que un acto de reconocimiento y como tal personalísimo, a que sea prestado por otras personas» (El reconocimiento de la filiación. Sus requisitos complementarios, Madrid, Editorial Trivium, 1993, pág. 34). Es de la misma opinión, CORDERO CUTILLAS, La impugnación de la paternidad..., op. cit., pág. 66. 
cha a partir de la que se entienda sucedido el fallecimiento del esposo, salvo prueba en contrario, y no desde la resolución judicial [párrafo segundo del art. $\left.195^{106} \mathrm{CC}\right]^{107}$. Finalmente, en caso de divorcio o separación legal, el cómputo se realizará a partir del cese efectivo de la vida conyugal y no desde que la sentencia sea firme ${ }^{108}$. Es decir, antes de dictarse una sentencia de divorcio, ésta podrá haber sido precedida de una previa separación de hecho o de Derecho, iniciándose a partir de este momento el cómputo del plazo $^{109}$.

\section{COLISIÓN DE PRESUNCIONES}

En el supuesto de colisión del artículo 117 con el artículo 116 del Código civil, para que sea de aplicación el artículo 117 será necesario que se produzca el nacimiento el menor dentro de los ciento ochenta días siguientes a la celebración del matrimonio de los cónyuges. Sin embargo, conviene tener presente que si el nacimiento se produce con posterioridad a dicho plazo, será de aplicación la regla general establecida en el artículo 116 del Código civil.

Por otra parte, en caso de producirse una separación de hecho antes del nacimiento del menor concebido con anterioridad a la celebración del matrimonio, se podrán aplicar de forma indistinta cualquiera de estos preceptos. Así, podrá ser de aplicación el artículo 117 debido a que el menor ha nacido dentro de los ciento ochenta días siguientes al matrimonio de los cónyuges o, por el contrario, el artículo 116 puesto que su nacimiento se ha producido antes de los trescientos días siguientes a la separación de hecho.

Otro supuesto de interés, se centra en la posibilidad de que tras la disolución de matrimonio por fallecimiento del esposo, la madre embarazada contraiga segundas nupcias al poco tiempo del fallecimiento, naciendo el hijo con anterioridad a los trescientos días siguientes a la disolución el vínculo anterior. Supuesto en el que la presunción prevista por el artículo 116 del Código civil abarcaría a

106 «Toda declaración de fallecimiento expresará la fecha a partir de la cual se entienda sucedida la muerte, con arreglo a lo preceptuado en los artículos precedentes, salvo prueba en contrario»

107 Vid., POZO VILCHES, op. cit., pág. 35.

108 En este sentido, vid., la Resolución de la DGRN de 22 de mayo de 1991, recogida por FÉREZ FERNÁNDEZ y GARRIGA GORINA, op. cit., págs. 1065-1076.

109 Vid., CORDERO CUTILLAS: «Presunción de Paternidad (arts. 116 y 117 CC)», en Historia y derecho: estudios jurídicos en homenaje al profesor Arcadio GARCÍA SANZ, Luis Fernando MARTÍNEZ VÁZQUEZ DE CASTRO (coord.), 1995, pág. 211. 
ambos esposos, debido a que el hijo podría nacer antes de los trescientos días siguientes a la disolución del primer matrimonio y dentro de los ciento ochenta días siguientes a la celebración del segundo, por lo que existiría una doble presunción de paternidad ${ }^{110}$.

En la actualidad, este supuesto tiene cabida, de una parte, porque con la Ley 30/1981, de 7 de julio, por la que se modifica la regulación del matrimonio en el Código Civil y se determina el procedimiento a seguir en las causas de nulidad, separación y divorcio, se eliminó el artículo 45.2 ${ }^{111}$ del Código civil. Precepto con el que se controlaban los matrimonios realizados por viudas o mujeres cuyo matrimonio había sido anulado dentro de los plazos establecidos por el derogado artículo 108 del Código civil, donde se preveía la presunción de paternidad $^{112}$. De otra, porque con la reforma realizada por Ley 30/1981, de 13 de mayo, no se han aportado soluciones a esta problemática. Por ello, se ha planteado la cuestión de cuál debe ser el precepto de aplicación en caso de esta colisión de presunciones.

Esta situación ha sido resuelta por el Código civil de Cataluña a favor del segundo marido, al establecer en su artículo 235-5 que: «3. Si dentro de los trescientos días siguientes a la disolución o a la nulidad ha tenido lugar un nuevo matrimonio de la madre, se presume que los nacidos después de la celebración de este matrimonio son hijos del segundo marido».

En este sentido, CORDERO CUTILLAS ${ }^{113}$-con acierto- sostiene que la posesión de estado será fundamental para el segundo esposo, pero en caso de oposición de la familia del primero, siempre cabrá la posibilidad de que no coincidiese con la paternidad real y, por tanto, si la madre contrae segundas nupcias y está embarazada, lógico es que el hijo sea biológicamente del segundo esposo, pero se podría haber dado la posibilidad de cohabitación con el primer esposo en un tiempo próximo al óbito, cuando mantuviera una doble relación.

En suma, el artículo 116 del Código civil abarcará a ambos esposos, aunque la concepción será matrimonial en el primer matrimonio

110 Vid., CORDERO CUTILLAS, «Presunción de Paternidad..., op. cit., pág. 213.

111 Decía el mencionado precepto: «Está prohibido el matrimonio: 2. A la viuda durante los trescientos un días siguientes a la muerte de su marido, o antes de su alumbramiento si hubiese quedado encinta, y a la mujer cuyo matrimonio hubiera sido declarado nulo, en los mismos casos y términos, a contar desde su separación legal». 41.

112 Vid., CORDERO CUTILLAS: La impugnación de la paternidad..., op. cit., pág. 113 La impugnación de la paternidad..., op. cit., págs. 41-42. 
y no matrimonial en el segundo. Lógicamente sólo uno podrá ser el padre, cuestión que se resolverá por vía judicial y por medio de la práctica de la prueba del ADN, prueba que se puede realizar sobre personas ya fallecidas.

Por otra parte, conviene precisar que en caso de oposición, lógico será esperar a la resolución judicial para que sea el Juez el que determine mediante las pruebas biológicas quién es el padre. Mientras que si no hubiese oposición por parte de la familia del primer esposo, lo normal será que el hijo se inscriba como hijo matrimonial del segundo esposo -si así lo deciden ambos-, ya sea dentro o fuera de pla$\mathrm{ZO}^{114}$.

Asimismo, si la inscripción se realiza dentro de plazo, la filiación paterna quedará determinada conforme a los artículos 115, 116 y 117 del Código civil, una vez constatada tanto la maternidad de la madre casada, como el matrimonio de ella con el segundo esposo. Sin embargo, el encargado del Registro Civil deberá realizar las averiguaciones que estime oportunas [art. 28 LRC], siempre que el menor nazca dentro del plazo establecido por el artículo 117, con la finalidad de descartar la existencia tanto de declaración de desconocimiento, como de matrimonio próximo anterior que pudiera dar origen a una colisión con el segundo.

En caso de que no hubiese oposición de la familia del primer matrimonio, cabe deducir que es lógico pensar que el encargado del Registro civil lo inscriba como hijo del segundo esposo, pero si existiese oposición, deberá remitirlo a la vía judicial para que sea el Juez de lo Civil quien determine cuál de las dos presunciones es la que se aproxima más a la verdad biológica. Por último, si la inscripción se realiza fuera de plazo, se deberá realizar a través de expediente gubernativo, en el que serán oídos todos los interesados entre los que se incluyen los herederos del primer esposo, de forma que si hubiera oposición se podría diferir a la vía judicial.

\section{REFLEXIONES CONCLUSIVAS}

Conforme al Código civil la presunción de paternidad aunque se trata de una presunción única, presenta ciertas matizaciones. Así, la

114 En este sentido, vid., CÁMARA ÁLVAREZ, Comentarios al Código Civil..., op. cit., pág. 301; VIDAL MARTÍNEZ: El hijo legítimo. Su concepto y determinación en el Código civil español, Montecorvo, Madrid, 1974, pág. 225. 
dicción del artículo 116, deja entrever que todos los hijos nacidos después del matrimonio de los cónyuges y con anterioridad a los trescientos días siguientes a la disolución o separación legal o de hecho de aquéllos, son presuntamente del marido, aunque su concepción haya sido anterior a la celebración de las nupcias.

Por otra parte, concurre una doble presunción -de conformidad con la declaración de desconocimiento del art. 117 CC-. De modo que, los hijos nacidos dentro del período previsto por el precepto, son hijos matrimoniales, con la excepción de que conste y se pueda realizar la correspondiente declaración auténtica. Esto, que permite al marido desconocer la paternidad del menor que nace dentro del período marcado sin necesidad de acudir a la vía judicial, se justifica en que la concepción se ha producido en un momento anterior a la celebración de las nupcias. Además, cabe la posibilidad de que el esposo no formule dicha declaración, bien porque tenía conocimiento del estado de gestación, lo que comporta un reconocimiento tácito de su paternidad o, por desconocimiento de tal circunstancia.

En suma, si el menor nace dentro del plazo de los ciento ochenta días siguientes a la celebración del matrimonio y el marido no efectúa la declaración auténtica en contrario, la paternidad le será atribuida, innegablemente, tanto por la presunción existente del artículo 116 del Código civil, como por la confluencia del reconocimiento tácito efectuado por éste.

En caso de celebración de matrimonio por poderes en el que no ha existido cohabitación por los cónyuges, conviene precisar que si la esposa alumbra dentro de los ciento ochenta días siguientes a la celebración del matrimonio, lo normal es que no se cuestione la presunción de paternidad, debido a que éste no puede destruir algo que no existe. Y en el supuesto de que se realice la inscripción de la filiación matrimonial en el Registro, el esposo deberá solicitar la rectificación del asiento inexacto por medio del juicio declarativo [art. 92 LRC].

En síntesis, este supuesto contenido en el artículo 117, puede originar la inoperancia de la presunción del artículo 116 del Código civil mediante un comportamiento activo del marido. Asimismo, si no ejercita acciones extrajudiciales para rebatir la presunción de paternidad, ésta se mantendrá debiéndola destruir por la vía judicial. Finalmente, los plazos comenzarán cuando sea sabedor del nacimiento del menor y los medios de prueba alegados a favor del marido -es decir, la manifestación de la lejanía física- serán de fácil demostración. 
En el supuesto de concepción anterior al matrimonio, dos son las situaciones que claramente se diferencian:

- Que el menor nazca con posterioridad a los ciento ochenta días siguientes a la celebración del matrimonio de los cónyuges. En este caso, aunque lo normal es que el esposo recurra a la vía judicial por medio de las acciones de impugnación de la paternidad [arts. 136 y $137 \mathrm{CC}$ ] al subsistir un vicio del consentimiento basado en la creencia de la concepción constante el matrimonio, quizás sería más idóneo acudir al artículo 138 del Código civil. La diferencia de aplicación de uno u otro precepto radica en el comienzo de los plazos. Así, si se aplica el artículo 138 comenzará desde el momento en que el esposo salga de su error, mientras que si se aplica el artículo 136 será desde la inscripción de la filiación en el Registro Civil.

- Que el menor nazca con anterioridad a los ciento ochenta días siguientes a la celebración del matrimonio. Caso en el que al estar dentro del periodo previsto por el artículo 117 del Código civil, si el marido estuviese en la creencia de que ha sido fruto de nacimiento prematuro y si sale de su error, en ese momento, podrá formular la acción de desconocimiento. Declaración que podrá ser formulada únicamente por él, salvo que sea demostrable -por su esposa- que era conocedor del estado de gestación de su esposa con anterioridad a la celebración de las nupcias.

En caso de hijo de concepción nupcial nacido dentro del periodo de los ciento ochenta días, el marido -al cumplirse lo establecido por el CC- podrá destruir la presunción de paternidad, salvo que operasen las excepciones establecidas en el texto legal. Por su parte, el Código civil de Cataluña prevé la imposibilidad de destruir la presunción de paternidad, en caso de que la madre demuestre la existencia de relaciones sexuales con el esposo durante el periodo legal de concepción.

Por cuanto atañe a la paternidad provocada por medios artificiales, conviene precisar que la presunción legal de paternidad opera de forma inequívoca, puesto que el hijo procede biológicamente del marido. Asimismo, a los hijos nacidos con las técnicas de reproducción asistida, les será de aplicación las normas de los artículos 116 y 117 del Código civil. Con todo, para la determinación de la paternidad influirá el consentimiento a dichas técnicas. Por ello, se considera que para la realización de la inseminación artificial, el consentimiento 
prestado podría ser entendido como un consentimiento tácito, al objeto de evitar que el esposo realice la acción de desconocimiento.

Por lo que a la declaración auténtica se refiere, es la vía establecida por el artículo 117 del Código civil, para destruir la presunción de paternidad de los hijos nacidos dentro de los ciento ochenta días siguientes a la celebración del matrimonio. Este precepto prevé la existencia de dos tipos de declaraciones: la unilateral -es decir, la efectuada por el esposo- y, la bilateral realizada por ambos cónyuges.

En la actualidad, la doctrina se encuentra dividida sobre el alcance de la declaración auténtica. Así, aunque un sector entiende que se ha realizar en escritura pública, otros, por el contrario aprecian que bien puede hacerse en documento público o privado, y que lo lógico es que su formalización se realice ante el encargado del Registro Civil. Este último deberá incorporarla al acta de nacimiento del menor, debido a que el marido lo que realmente persigue es la autenticidad de ésta y, por ello, no sería suficiente formalizarla ante fedatario público.

En este sentido, también el Código civil de Cataluña prevé que la declaración sea auténtica y que tenga entrada en el Registro civil, pero para ejercitar la declaración de desconocimiento, ésta se deberá realizar en los seis meses siguientes al nacimiento, con la finalidad de evitar los posibles problemas que se podrían suscitar sobre la determinación del momento exacto en que el padre conoce el nacimiento del hijo atribuido por Ley.

Las excepciones previstas por el artículo 117 del Código civil, en las que el esposo no podrá desconocer la paternidad mediante la declaración auténtica en contrario son: que hubiese reconocido la paternidad -expresa o tácitamente- o, conocido el embarazo de la mujer con anterioridad a la celebración de las nupcias. En idéntico sentido se pronuncia el Código civil de Cataluña, pero si bien añade una tercera excepción concretada en la demostración por la madre de la existencia de relaciones sexuales con el esposo durante el período legal de la concepción. Supuestos todos cuya finalidad es invalidar o hacer ineficaz el desconocimiento del padre, dejando expedita la vía para que pueda tener lugar la declaración auténtica, cuyo objeto es destruir la presunción de paternidad. Sin embargo, en caso de realizarse la inscripción, lo cierto es que el encargado del Registro Civil deberá realizar cuantas indagaciones estime oportunas para averiguar si tuvo o no lugar el reconocimiento previo y, deberá ser la madre la que demuestre que aquél se produjo, debiendo acudir a la vía judicial, únicamente, en caso de que éste no se pueda probar. 
Por lo que a la disolución y separación de hecho o de Derecho de los cónyuges se refiere, el artículo 116 del Código civil, hace referencia al término ‘antes de`, por lo que lógico es pensar que el día trescientos ya no opera. Este precepto que presenta como novedad la inclusión en su texto de la separación de hecho, comporta que subsista el vínculo matrimonial, por lo que la presunción se fundamenta en la convivencia conyugal durante el periodo de concepción. Convivencia conyugal que cesará en función de la existencia o no de relaciones esporádicas.

Por cuanto atañe a la posible colisión de presunciones de los artículos 116 y 117 del Código civil, conviene precisar que para que sea de aplicación el artículo 117 es necesario que el nacimiento tenga lugar dentro de los ciento ochenta días siguientes a la celebración del matrimonio de los cónyuges, mientras que si el nacimiento se produce con posterioridad a dicho plazo, indudablemente, será de aplicación la regla general del artículo 116. Sin embargo, en caso de producirse una separación de hecho antes del nacimiento del menor concebido con anterioridad a la celebración del matrimonio, se podrán aplicar de forma indistinta cualquiera de estos preceptos.

Finalmente, en caso de disolución de matrimonio por fallecimiento del esposo, si la madre embarazada contrajese segundas nupcias tras la muerte de aquél, la presunción prevista por el artículo 116 abarcaría a ambos maridos, comportando ello una doble presunción de paternidad. La concepción será matrimonial en el primer matrimonio y extramatrimonial en el segundo y la cuestión de la concepción se resolverá vía judicial y mediante la prueba del $\mathrm{ADN}$, puesto que en realidad solo uno de ellos podrá ser el padre biológico del menor. Esta cuestión ha sido resuelta a favor del segundo marido, por el Código Civil de Cataluña.

\section{BIBLIOGRAFÍA}

ALBALADEJO GARCÍA, Manuel: Curso de Derecho Civil. IV. Derecho de Familia, Librería Bosch, Barcelona, 1984, 2. ${ }^{\text {a }}$ ed.

BLASCO GASCÓ, Francisco: «La filiación», en AA.VV., Derecho de familia, Vicente Luis MONTÉS PENADÉS (Coord.), Tirant lo Blanch, Valencia, 1991, págs. 351-439.

- Derecho de familia, Tirant Lo Blanch, Valencia, 1997, 3. ${ }^{\text {a ed. }}$

CÁMARA ÁLVAREZ, Manuel de la: «El nuevo derecho de la filia- 
ción», en AA.VV., El nuevo Derecho de la familia español, Reus, Madrid, 1982, págs. 31-96.

- Comentarios al Código Civil y Compilaciones Forales, T. III, Vol. I, Manuel ALBALADEJO GARCÍA (Dir.), Edersa, Madrid, 1984.

CASTRO Y BRAVO, Federico de: Derecho Civil de España, Ed. Civitas, Madrid, 1984.

CORDERO CUTILLAS, Icíar: «Presunción de Paternidad (arts. 116 y 117 (C)», en Historia y derecho: estudios jurídicos en homenaje al profesor Arcadio GARCÍA SANZ, Luis Fernando; MARTÍNEZ VÁZQUEZ DE CASTRO (coord.), 1995, págs. 201-220.

- La impugnación de la paternidad matrimonial, Colección de Estudios Jurídicos, $\mathrm{n}^{\circ}$ 6, Publicación de la Universidad Jaime Primero, Castellón, 2001.

DÍAZ-AMBRONA BARDAJÍ, M ${ }^{\mathrm{a}}$ Dolores y HERNÁNDEZ GIL, Francisco: Lecciones de Derecho de Familia, Centro de Estudios Ramón Areces S.A., Madrid, 1999.

DÍEZ DEL CORRAL RIVAS, Jesús: «La inscripción de la filiación en el Registro civil», $R D N$, n. 123, enero-marzo, 1-1984, págs. 7-66.

DÍEZ-PICAZO, Luis y GULLÓN BALLESTEROS, Antonio: Instituciones de Derecho civil, Derechos Reales, Derecho de Familia, Derecho de Sucesiones, Vol. II, Tecnos, Madrid, 1995.

- Sistema de Derecho civil. IV. Derecho de Familia. Derecho de Sucesiones, Vol. IV, Luis DÍEZ-PICAZO y Antonio GULLÓN BALLESTEROS (coord.), Tecnos, Madrid, 2002, 6. ${ }^{\mathrm{a}}$ ed.

FÉREZ FERNÁNDEZ, $M^{\mathrm{a}}$ Dolores y GARRIGA GORINA, Margarita: «La presunción de paternidad matrimonial del artículo 116 en el caso de separación de hecho. Comentario a la RDGRN de 22 de mayo de 1991», en RJCat, Vol. 91, nº. 4, 1992, págs. 1065-1076.

GARCÍA CANTERO, Gabriel: «La filiación», en Derecho Civil español, Común y Foral. IV. Derecho de Familia, Relaciones paternofiliales y tutelares, Vol. II, de José Castán Tobeñas, Reus, Madrid, 1985, 9. edición revisada y puesta al día, págs. 11-200.

GARRIDO MELERO, Martín: «Reflexiones sobre el Derecho de filiación en Cataluña y sus relaciones con el Código Civil», Revista Jurídica del Notariado, n. 7, Julio-Septiembre 1993, págs. 202204.

GARCÍA ZARANDIETA, Serafín: «La filiación y el Registro civil (Es- 
tudio sistemático de la reforma introducida por la Ley 11/1981, de 13 de mayo en el Código civil)», en BIMJ, n. 1272, 15 de abril, págs. 3-18; n. 1274, 5 de mayo, Madrid, 1982, págs. 3-15.

GETE-ALONSO Y CALERA, M. ${ }^{a}$ Carmen y BLASCO GASCÓ, Francisco: La nueva regulación de la filiación en el derecho catalán, Tirant lo Blanch, Valencia, 1992.

JIMÉNEZ MUÑOZ, Francisco: La reproducción asistida y su régimen jurídico, Madrid, 2012.

LACRUZ BERDEJO, José Luis; SANCHO REBULLIDA, Francisco de Asís: Elementos de Derecho civil. IV. Derecho de Familia, Ed. Experimental Librería Bosch, Barcelona, 1982.

LASARTE ÁlVAREZ, Carlos: Principios del Derecho Civil, Derecho de Familia, T. VI, Marcial Pons, Madrid, 2011, 10. ${ }^{\text {a }}$ ed.

LEONSEGUI GUILLOT, Rosa Adela: «Problemas jurídicos planteados por las nuevas técnicas de reproducción asistida, $B F D$, 8-9, 1995, págs. 237-264.

- «La maternidad portadora, sustituta, subrogada o de encargo», BFD págs. 1.327-1.354.

LÓPEZ PELÁEZ, Patricia: «Relaciones civiles derivadas de la fecundación post mortem», BFD, 6, 1994, págs. 19-142.

— «La filiación de los niños y niñas nacidos en virtud de contratos de gestación por sustitución en el Derecho español», Derecho de la persona: acogimiento y adopción, discapacidad e incapacitación, filiación y reproducción asistida, personas mayores, responsabilidad penal del menor y otras cuestiones referidas a la persona como sujeto del derecho, Isaac RAVETLLAT BALLESTE (Coord.), Barcelona, 2011, págs. 89-136.

LLEDO YAGÜE, Francisco: Acciones de Filiación, Ed., La Ley, Madrid, 1987, 2. ${ }^{\text {a }}$ ed.

MARTÍN-GRANIZO FERNÁNDEZ, Mariano: Código civil. Doctrina y Jurisprudencia, T. I, José Luis ALBACAR LÓPEZ (Dir.), Trivium, Madrid, 1991.

MARTÍNEZ-CALCERRADA GÓMEZ, Luis: El nuevo Derecho de familia. II. (Régimen sobre Filiación y Sociedad de Gananciales) -Teoría, norma y practica- Análisis de la Ley de 13 de mayo de 1981, Graficas Espejo, Madrid, 1981.

MORETÓN SANZ, M. ${ }^{a}$ Fernanda: «El nuevo sistema de protección de 
la persona con autonomía limitada: de la incapacitación judicial a la discapacidad y dependencia», en La protección de las personas mayores, Carlos LASARTE ÁLVAREZ (Dir.) y M. ${ }^{a}$ Fernanda MORETÓN SANZ (Coord.), Madrid, 2007, pp. 31-49.

OCAÑA RODRÍGUEZ, Antonio: La filiación en España, Comares, Granada, 1993.

PEÑA BERNALDO DE QUIRÓS, Manuel: «Comentario a los artículos 108 a 141 del Código civil (De la paternidad y filiación)», en Comentarios a las Reformas del Derecho de Familia, Vol. I, Tecnos, Madrid, 1984, págs. 774-1023.

- Derecho de Familia. Servicio de publicaciones, Facultad de Derecho Universidad Complutense, Madrid, 1989.

POUS DE LA FLOR Ma Paz y LEONSEGUI GUILLOT Rosa Adela: «Investigación de la paternidad y derechos fundamentales: su protección jurisdiccional», Cuestiones actuales de la jurisdicción en España, Alfredo MONTOYA MELGAR (Coord.), Madrid, 2010, págs. 621-638.

POZO VILCHES, Juan: El reconocimiento de la filiación. Sus requisitos complementarios, Madrid, Editorial Trivium, 1993.

PUIG BRUTAU, José: Fundamentos de Derecho Civil. IV. Familia, matrimonio, filiación, ed. Bosch, Barcelona, 1985, 2. ${ }^{\text {a ed. }}$

QUESADA GONZÁLEZ, M. Corona: Promiscuidad sexual y determinación jurídica de la paternidad, Tecnos, Madrid, 1993.

RIVERO HERNÁNDEZ, Francisco: Elementos del Derecho Civil. IV. Derecho de familia, Vol. II, Bosch, Barcelona, 1989, 3. ${ }^{\text {a }}$ ed.

- La presunción de paternidad legitima, Estudio de Derecho Comparado y Derecho Español, Tecnos, Madrid, 1971.

- «El desconocimiento de la paternidad del hijo nacido dentro de los ciento ochenta días siguientes al matrimonio», en RJNav, Homenaje al profesor SANCHO REBULLIDA, enero-junio, n. 15, 1993, págs. 271-292.

RODRÍGUEZ ADRADOS, Antonio: «La filiación», $R D N$, CXX, abriljunio, 2-1983, págs. 281-434.

ROYO MARTÍNEZ, Miguel: Derecho de familia, Imprenta Suarez, Sevilla, 1949, 1. ${ }^{\mathrm{a}}$ ed. 
SANCHO REBULLIDA, Francisco de Asís: «La filiación en la Ley Foral de 1 de abril de 1987», en RJNa, 1990, págs. 31-68.

SERNA MEROÑO, Encarnación: La reforma de la filiación, Montecorvo, Madrid, 1985.

VERDERA SERVER, Rafael: Determinación y acreditación de la filiación, Ed. Boch, Barcelona, 1993.

VIDAL MARTÍNEZ, Jaime: El hijo legítimo. Su concepto y determinación en el Código civil español, Montecorvo, Madrid, 1974.

\section{VII. ÍNDICE DE RESOLUCIONES}

\section{Tribunal Supremo:}

— STS de 16 abril de 1969.

\section{Dirección General de los Registros y del Notariado:}

- Resolución de 22 de mayo de 1991.

- Resolución de 2 de agosto de 1991 (RJ 1991, 6304).

— Resolución de 11 de octubre de 1991 (La Ley 9286/1991).

- Resolución de 22 de mayo de 1992 (La Ley 8334/1992).

- Resolución de 26 de junio de 1992 (La Ley 9449/1992).

- Resolución de 1 de febrero de 1993 (RJ 1993, 1312).

- Resolución de 5 de marzo de 1994.

- Resolución de 22 de noviembre de 1994 (La Ley 12484/1994).

- Resolución de 30 de noviembre de 1995 (RJ 1996, 1400).

— Resolución de 10 de febrero de 1996 (RJ 1996, 3409).

— Resolución de 19 de octubre de 1996 (RJ 1997, 3570).

- Resolución de 18 de noviembre de 1996 (RJ 1997, 6907). 
